\title{
Phylogeographic patterns of steppe species in Eastern Central Europe: a review and the implications for conservation
}

\author{
Łukasz Kajtoch ${ }^{1}$ - Elżbieta Cieślak ${ }^{2}$ - Zoltán Varga ${ }^{3}$. \\ Wojciech Paul $^{2}$ • Miłosz A. Mazur ${ }^{4}$ Gábor Sramkó G,6 $^{5}$ \\ Daniel Kubisz ${ }^{1}$
}

Received: 16 April 2015/Revised: 20 January 2016/Accepted: 12 February 2016/

Published online: 26 February 2016

(C) The Author(s) 2016. This article is published with open access at Springerlink.com

\begin{abstract}
The phylogeography of species associated with European steppes and extrazonal xeric grasslands is poorly understood. This paper summarizes the results of recent studies on the phylogeography and conservation genetics of animals (20 taxa of beetles, butterflies, reptiles and rodents) and flowering plants (18 taxa) of such, "steppic" habitats in Eastern Central Europe. Most species show a similar phylogeographic pattern: relatively high genetic similarity within regional groups of populations and moderate-to-high genetic distinctiveness of populations from currently isolated regions located in the studied area. This distinctiveness of populations suggests a survival here during glacial maxima, including areas north of the Bohemian Massif-Carpathians arc. Steppic species generally do not follow the paradigmatic patterns known for temperate biota (south-north "contraction-expansion"), but to some extent are similar to those of arctic-alpine taxa. There are three main groups of taxa within Eastern Central Europe that differ in their contemporary distribution pattern, which may reflect historical origin and expansion routes. Present diversity patterns of the studied steppic species suggest that they share a unique genetic signature and distinct assemblages exist in each of the now isolated areas rich in steppic habitats. At least some of these areas probably act as present "interglacial refugia" for steppic species. This study strongly supports the need to protect steppic species throughout their entire ranges in the region, as the continuous destruction of steppic
\end{abstract}

Communicated by Jürgen Dengler.

Łukasz Kajtoch

lukasz.kajtoch@gmail.com

1 Institute of Systematics and Evolution of Animals, Polish Academy of Sciences, Krakow, Poland

2 W. Szafer Institute of Botany, Polish Academy of Sciences, Krakow, Poland

3 Department of Evolutionary Zoology, University of Debrecen, Debrecen, Hungary

4 Center for Biodiversity Studies, Opole University, Opole, Poland

5 Department of Botany, University of Debrecen, Debrecen, Hungary

6 MTA-ELTE-MTM Ecology Research Group, Budapest, Hungary 
habitats in some areas may lead not only to the disappearance of local populations, but also to the extinction of unique evolutionary units.

Keywords Biogeography $\cdot$ Genetics $\cdot$ Glacial $\cdot$ Interglacial $\cdot$ Refugium $\cdot$ Xeric grassland

\section{Introduction}

Phylogeographical studies in extra-Mediterranean Europe have so far been focused on temperate and arctic-alpine species. The results of numerous works on temperate plant and animal species have allowed generalisations to be made concerning their phylogeographic patterns (Hewitt 2000, 2004; Schmitt 2007). These reviews conclude that species adapted to temperate conditions have reacted to glaciations following a general phylogeographic paradigm, where species' range contracts during Pleistocene glaciations into southern refugia located basically in the area of the Mediterranean peninsulas, and subsequently the populations expand into other parts of the continent during interglacials (e.g. Taberlet et al. 1998; Petit et al. 2003). This "contraction-expansion" principle has recently been challenged, as many studies have suggested or proven that refugia were not restricted to the southern areas, but were present also in western, central and eastern Europe, mainly as local "northern" or "cryptic" refugia (Stewart and Lister 2001; Schmitt and Varga 2012; Bartha et al. 2015).

Other studies showed that the populations of boreo-montane species are either phylogeographically unstructured or only show a rather shallow differentiation between the zonal (taiga-associated) and montane populations (Taberlet et al. 1998; Schmitt 2007; exceptions: Schmitt and Haubrich 2008; Bajc et al. 2011). On the other hand, populations of arctic-alpine taxa must have been much more widely distributed during glaciations than in interglacials, including the Holocene (e.g. Schönswetter et al. 2005; Varga and Schmitt 2008; Schmitt 2009). For these taxa, the concept of refugium needs to be modified. The inclusion of the impact of climate changes in the meaning of the "refugium" has been postulated (e.g. Bennett and Provan 2008; Ashcroft 2010). That is why the term "warm stage refugia" was proposed to stress that some species (mainly the cold-adapted) experience their smallest ranges during warm periods and expand during glaciations (Holderegger and Thiel-Egenter 2008; Stewart et al. 2010). The phylogeography of the temperate and cold-adapted species allowed for a more comprehensive understanding of the history of European fauna and flora. A notion of an "individual response" of species to climatic oscillations, along with the idea of the disintegration of past ecosystems (i.e. those present during glacial periods) and the formation of ecosystems de novo without a close connection to the preceding ones has been proposed (Bhagwat and Willis 2008; Schmitt and Varga 2012).

However, a third group of organisms which are present in extra-Mediterranean Europe has been notoriously ignored: species adapted to dry and periodically warm conditions of the continental zone, mostly inhabiting steppes and other types of dry grasslands. The phylogeography of continental species was partly included in the reviews of Stewart et al. (2010) and Varga (2010), but mostly on the basis of chorological data, making the steppededicated parts of the above papers more thought-provoking than reviewing. The general disregard for continental elements in reviews about the phylogeography of European species could be explained by the relatively recent arrival of studies on this group (with the 


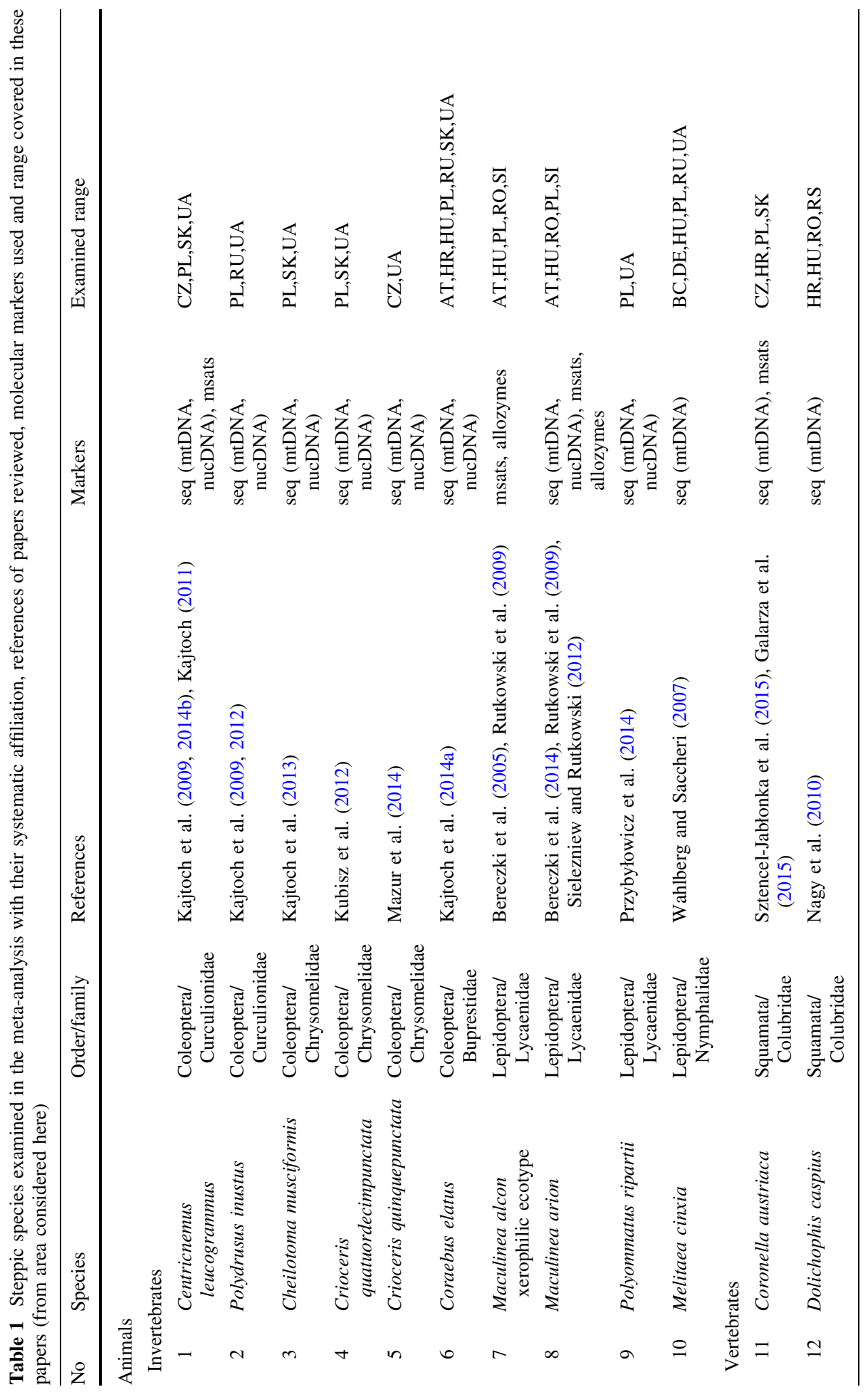




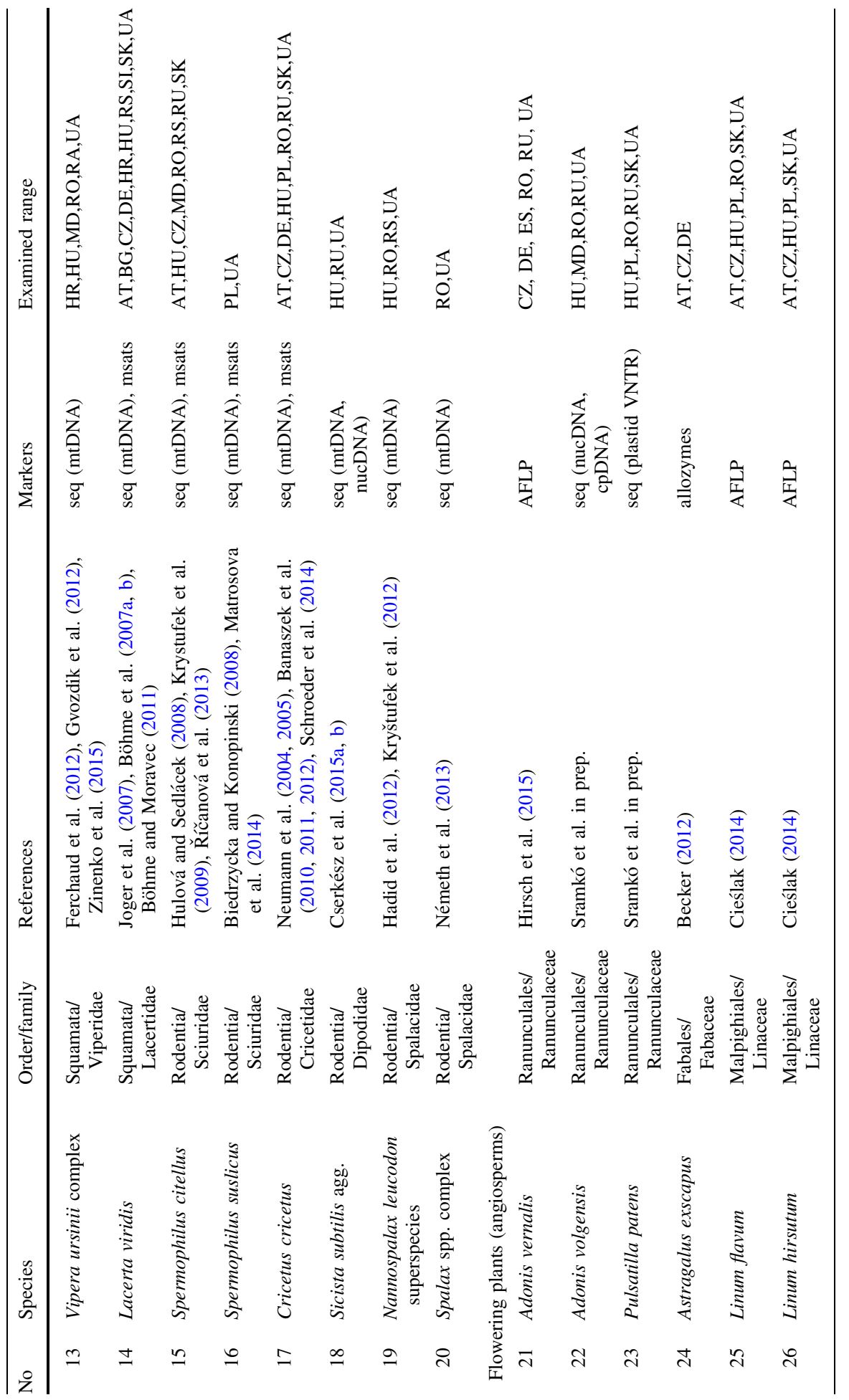




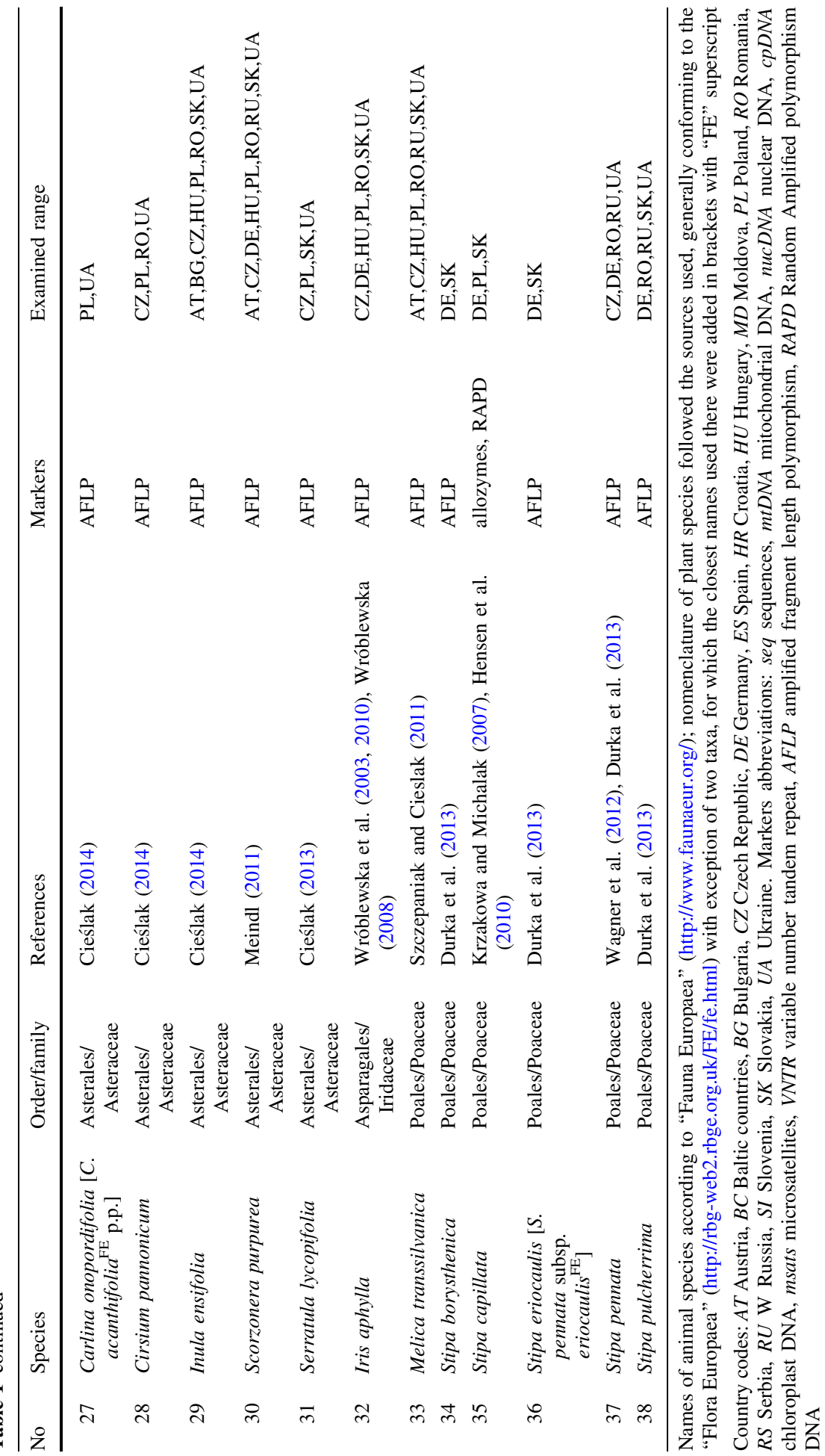


exception of Iberian steppes, which are probably only distantly related to Eurasian ones, and have a different origin; e.g. Ribera and Blasco-Zumeta 1998; González-Sampériz et al. 2010). The first phylogeographic papers dealing with steppe species were published in the first half of the 2000s and the majority of them only in the last decade (see Table 1 for compilation of references). The increasing amount of data on phylogeographic patterns in steppic species has allowed this group to be inserted into the general picture of the phylogeography of the European biota for the first time. This could be important, as steppic habitats sustain assemblages very rich in species, among which there are many taxa restricted only to this type of environment or even endemic to some steppic areas on a European or local scale (e.g. Pärtel et al. 2005; Mazur and Kubisz 2013; Dengler et al. 2014). Moreover, steppes and steppic species are among the most threatened in Europe due to natural (i.e. climatic and environmental) reasons, which restrict their distribution during woodland-dominated interglacial periods, and to the anthropogenic degradation and fragmentation of steppic patches, especially in the central part of Europe (Cremene et al. 2005; Janišová et al. 2011; Fekete et al. 2014). The situation of some steppic patches and populations is so serious (especially north of the Carpathians) that this could be the last chance for an appropriate sampling to be carried out for phylogeographic studies. Moreover, data on the distribution of steppes in the past suggests that different types of xeric and meso-xeric grasslands were much more abundant and widespread throughout Europe during glacial times. There were at least two variants of glacial steppes: cold steppes in front of glaciers (with co-occurrence of tundral elements) and more warm-adapted and meso-xeric meadow steppes known from southern areas (Willis and van Andel 2004; Markova et al. 2009). Xeric grasslands and meadow steppes could also persist as local components in the "non-analogous" assemblages of the lower latitude periglacial open zonobiom (see: current occurrence of cold-tolerant steppic species from Yakutia to Alaska; Yurtsev 1982, 2000; Ehlers and Gibbard 2004).

During interglacials (such as our current epoch, the Holocene), the natural steppes in Europe become basically restricted to the eastern and south-eastern regions, forming part of a long and narrow Eurasian steppe zone from the inner parts of the Pannonian Basin to NE China, although similar habitats (called dry/calcareous/xerothermic grasslands) are known from many dispersed localities in central Europe and the Balkan Peninsula (e.g. on steep slopes of hills and along river scarps) (Donita et al. 2003; Fekete et al. 2014; Pokorný et al. 2015). That range shift of steppe-like habitats probably influenced the phylogeography of steppic species, which might have been more widespread during ice ages (more severe climatic conditions notwithstanding, see Berman et al. 2011) but are currently experiencing range contractions. The current large-scale diversity patterns of steppe species follow a decreasing gradient from east to the west. This would imply a recent immigration from the east to the suitable habitats as genetic diversity should follow a similar east-to-west decreasing gradient. However, in light of the above vegetation historical reasoning, we could expect a more complicated pattern of genetic diversity supporting an alternative hypothesis of phylogeographic history (i.e. long-term persistence of steppic species' populations at the current western edges/patches of their distribution).

In this paper, we review the phylogeographic pattern in steppic species on their western part of their distribution, Eastern Central Europe (with adjoining East European ranges), where enough phylogeographic data have been accumulated, and where steppes, foreststeppes and extrazonal xeric grasslands are all represented. Specifically, we are inquiring for the following questions: 
1. Are the observed phylogeographic patterns congruent for all the reviewed steppic organisms?

2. If so, do these patterns conform either to the patterns observed for one presented by the so far analysed cold-adapted taxa or to the patterns known for temperate biota?

3. Did the mountain chains (i.e. the Bohemian Massif and/or the Carpathians) act as barriers for the steppic taxa?

4. Is there support for the east-to-west decreasing gradient in phylogeographic pattern?

5. Are there evident genetical 'traces' of the existence of extrazonal interglacial refugia and/or of several migrational waves of the steppic taxa during last Pleistocene cycles in the Eastern Central Europe?

Additionally, with bearing the limited quantity and quality of available data in mind, we also try to discuss topics of (i) the dual nature of 'refugia' of steppic taxa (i.e. presence of both 'warm stage' and 'cold stage' refugia); and (ii) the importance of the observed patterns in the context of conservation genetics of the highly-endangered steppic taxa.

\section{Methods}

\section{Examined area}

This review focuses on the available phylogeographic studies of species related to steppes and other similar types of dry grasslands (called also "calcareous" or "xerothermic", depending on the area and terminology in use). As we were interested mainly in species distributed in Eastern Central Europe, we generally narrowed our species choice to taxa

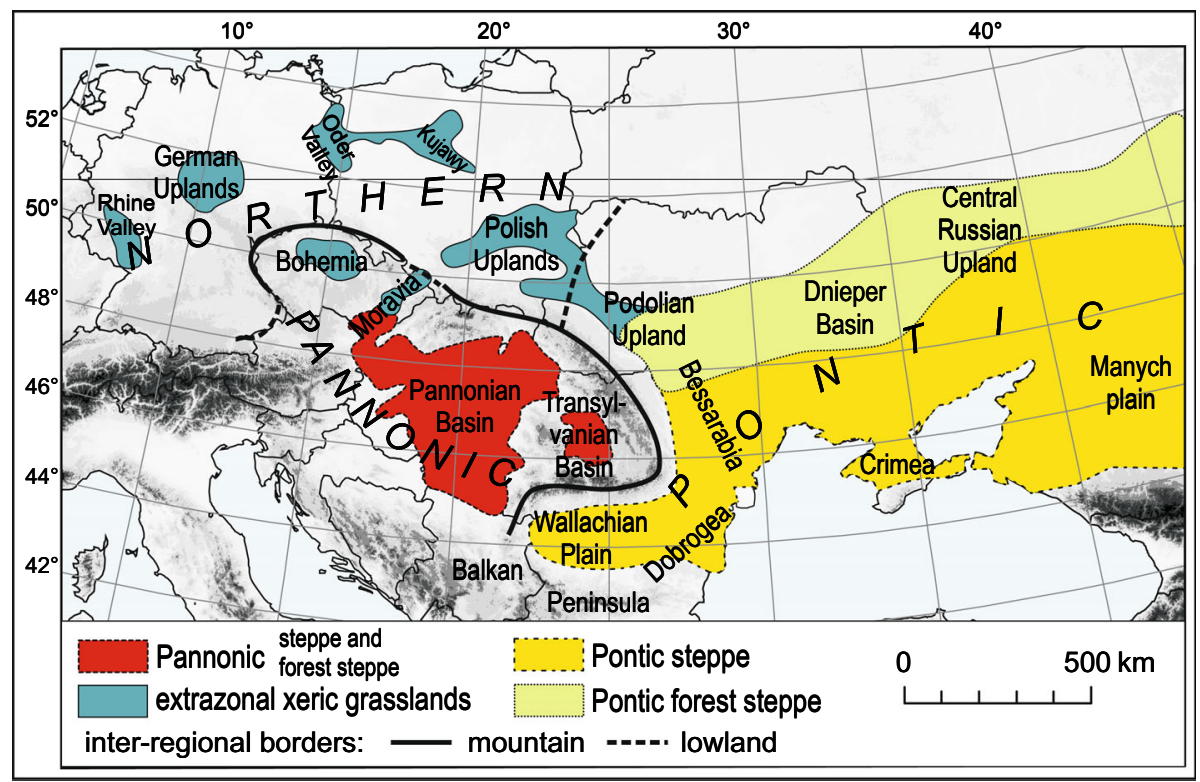

Fig. 1 Simplified map of the distribution of steppes and forest-steppes (Pontic and Pannonian) and xeric grasslands in Eastern Central Europe (with adjoining East European ranges) with their regionalisation as used in the review (Northern-Pannonic-Pontic). (Color figure online) 
which are distributed from Germany and Austria in the west to Ukraine in the east, and from the southern Baltic coast in the north via the Pannonian Basin to the northern part of the Balkan Peninsula in the south. We intentionally excluded from the reviewed area the central-Alpine dry valleys (Braun-Blanquet 1961) and xeric grasslands (alvars) on Baltic islands (Pettersson 1965) as from these areas phylogeographic and population genetics data were available for only one of the examined species (Astragalus exscapus; Becker 2012).

For the purposes of this review, we divided the area of Eastern Central Europe (with neighbouring areas of East Europe) into three different regions (Fig. 1), in respect to the Bohemian Massif-Carpathians arc:

1. The "Northern" region, comprising areas situated outwards from the arc-mainly Germany and Poland (Rhine and Oder Valleys, German and Polish Uplands, Kujawy Basin), with part of Belarus and the westernmost part of Ukraine (until the eastern end of the Lublin-Lviv Upland); this region was covered by an ice sheet (or was in its immediate foreland) during at least one Pleistocene glaciation, and currently features extrazonal, highly fragmented and isolated steppic patches.

2. The "Pontic" region, stretching to the east from the Northern one, as defined above, and from the East Carpathians, including areas along the border between Romania and Bulgaria (Wallachian Plain, Dobrogea region), Moldova (Bessarabian Upland), as well as the adjoining East European areas: most of Ukraine (Podolian Upland, Dnieper Basin, Crimea) and the steppic/forest-steppic belt of south-western Russia (Central Russian Upland) up to the northern foot slopes of the Caucasus (Manych plains); this region was never fully glaciated and it now constitutes the westernmost fragment of the continuous (zonal) Eurasian steppe belt.

3. The "Pannonic" region, comprising the areas within the Bohemian Massif-Carpathians arc (Bohemia, Moravia, Pannonian Basin, Transylvanian Basin) and the adjacent northernmost parts of the Balkan Peninsula to the west and southwest of the Danube; this region was never glaciated and sustains large extrazonal and edaphic (sandy and saline) steppic areas within the Pannonian Basin and its surroundings. Their "deviations" from the general zonality are discussed by Fekete et al. (2014).

\section{Data collection}

About one third of the studies on the following taxa were carried out by the authors of this review (see Table 1 for references). Moreover, we searched scientific literature with the use of the Google Scholar, Biological Abstracts, and PubMed databases, using the following keywords: "phylogeography", "population genetics", "conservation genetics", "Europe", "steppe", "dry grasslands", "calcareous" and "xerothermic". We mainly selected papers that examine populations across substantial parts of species ranges in Eastern Central Europe. We omitted eurytopic species which have ranges in both the continental zone of Eurasia and the Mediterranean region. We also decided to exclude papers on bird species. On the other hand, we included a few studies which are "in press", or in the final publication preparation stages (see Table 1 for references).

The final list of the steppic taxa for which genetic data is available includes 38 of them: six beetles, four butterflies, two species and one complex of snakes, one lizard, four species and two species complexes of rodents, and 18 flowering plant species, described in altogether 52 articles (Table 1). The nomenclature of taxa and systematic approaches throughout the paper follow the articles from which the data was derived. 


\section{Elaboration of genetic data}

Selected animal and plant taxa were investigated with the use of different types of molecular markers (DNA sequences or allelic data). Details about the methods and markers used for particular taxa are described in Information Box 1 and presented in Table 1 .

For a majority of the selected taxa, genetic data was available as basic diversity descriptors (see Box 1 for details). Usually, papers also included different types of algorithms and methods used in clustering and identification of genetic distinctiveness of the populations and individuals. Moreover, many of the scientific papers featured special maps visualizing how the genetic diversity of the populations refers to their geographic distribution. Use of different type of markers for elaborating genetic diversity and distinctiveness of populations could be problematic as they generally reflect different time-scales. Whereas mtDNA in animals and AFLPs and plastid haplotypes in plants are usually utilised for phylogeographic studies reflecting historical changes in taxa's genetics (usually dating back to several generations), SSRs are used for contemporary and more recent description of population genetics and demography, thus reflecting very recent changes in taxa's genetics (usually dating back to few generations). Therefore, SSRs were only used as an additional source of information about genetics of examined taxa since simultaneous use of both types of markers is common practice that allows for comprehensive phylogeographic and population genetic analyses (especially when a study has conservation implications). As mtDNA data are available for all animals examined, and either AFLPs and/or plastid data are available for all plants, it was possible to analyse and compare data within animals and within plants in a similar way (Fig. 2).

Information Box 1 Brief summary of molecular markers and techniques used in the reviewed papers dealing with phylogeography and population genetics of steppic species

\footnotetext{
Markers used in the studies reviewed

Allozymes [used for some plants and butterflies]

Mitochondrial DNA (mtDNA) - genes cytochrome oxidase subunits I and II (COI and COII) or cytochrome-b (CytB) and non-coding control region (CR) [used for animals]

Plastid DNA (cpDNA) - intergenic spacers (accD-psaI, trn H-psbA) [used for plants]

Nuclear sequences-Elongation Factor $1-\alpha($ EF-1 $\alpha)$ gene, Interphotoreceptor Retinoid-Binding Protein (IRBP) gene, $L F Y$ gene intron, Internal Transcribed Spacers of ribosomal DNA (rITS) [used for animals and plants]

Microsatellites (SSRs) [used for animals]

Amplified Fragment Length Polymorphism (AFLP) [used for plants]

Random Amplified Polymorphism DNA (RAPD) [used for plants]

Variable Number Tandem Repeat (VNTR) [used for plants]

Analyses applied in the studies reviewed

Haplotype and nucleotide diversities [calculated for sequence markers]

Heterozygosity and allelic richness [calculated for allelic markers]

Phylogenetic trees reconstruction [calculated for sequence markers]

Haplotype (or allele) network building [calculated for both types of markers]

Genotype assignment to clusters [calculated for allelic markers]

Isolation by Distance in Mantel Test (IBD-MT) [calculated for both types of markers]

Analysis of Molecular Variance (AMOVA) [calculated for both types of markers]

Fixation index $\mathrm{F}_{\mathrm{ST}}$ [calculated for both types of markers]
} 

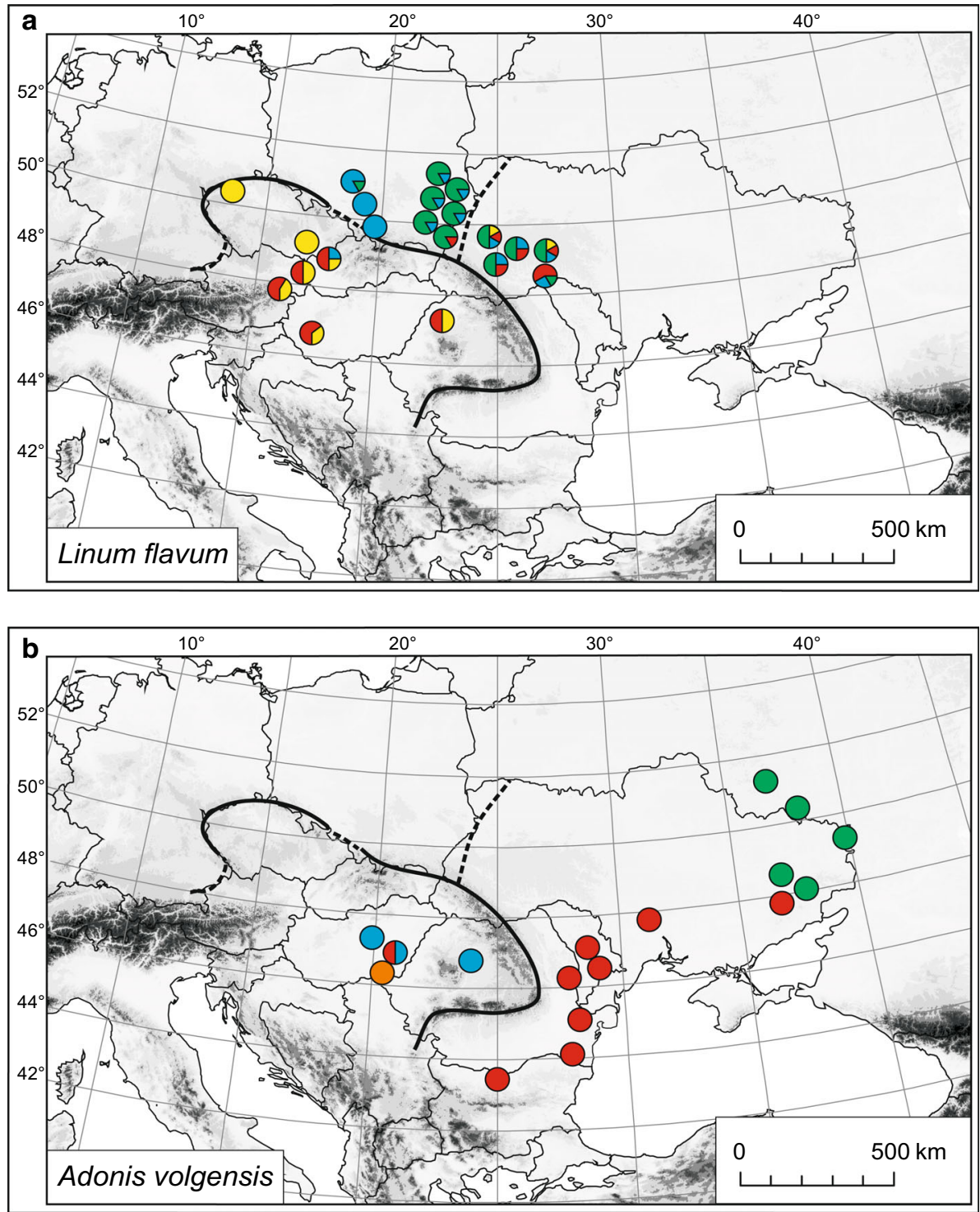

Fig. 2 Phylogeographic patterns observed for eight selected steppic species from Eastern Central Europefour plants $(\mathbf{a}-\mathbf{d})$ and four animals $(\mathbf{e}-\mathbf{h})$. The colours/greyscale of the circles indicate generalized data about the presence of distinct phylogenetic lineages and/or genetic clusters identified based on genetic (phylogeographic, population and conservation genetics) studies. Sources of data: Linum flavum (Linaceae): Cieślak 2014; Adonis volgensis (Ranunculaceae): Sramkó et al. in prep.; Iris aphylla (Iridaceae): Wróblewska et al. 2003, 2010; Wróblewska 2008; Scorzonera purpurea (Asteraceae): Meindl 2011; Centricnemus leucogrammus (Curculionidae): Kajtoch et al. 2009, 2014a; Kajtoch 2011; Melitaea cinxia (Nymphalidae): Wahlberg and Saccheri 2007; Coronella austriaca (Colubridae): Sztencel-Jabłonka et al. 2015; Galarza et al. 2015; Cricetus cricetus (Cricetidae): Neumann et al. 2004, 2005; Banaszek et al. 2010, 2011, 2012; Schroeder et al. 2014. (Color figure online) 

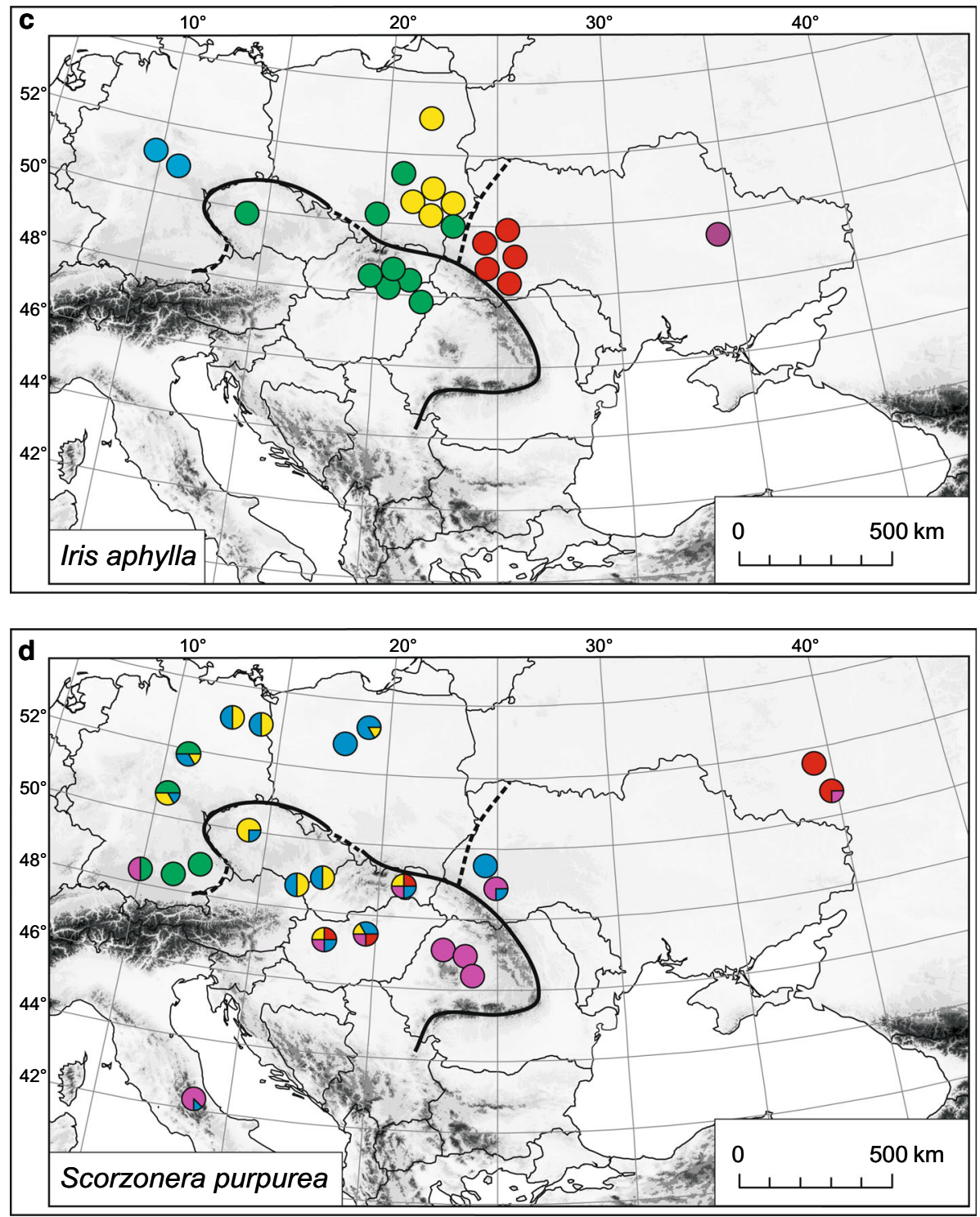

Fig. 2 continued

We examined all of these data to identify the following characters of the selected steppic taxa:

Character (1): Intra-regional diversity-genetic diversity detected on an intra-regional geographic scale (i.e. among populations within each of the three regions as defined above, intra-population diversity notwithstanding), estimated (generalized) into three categories: (i) "low" (lack of diversity or with very low values of appropriate descriptors, e.g. interpopulation haplotype diversity or heterozygosity below 0.25); (ii) "moderate" (haplotype 

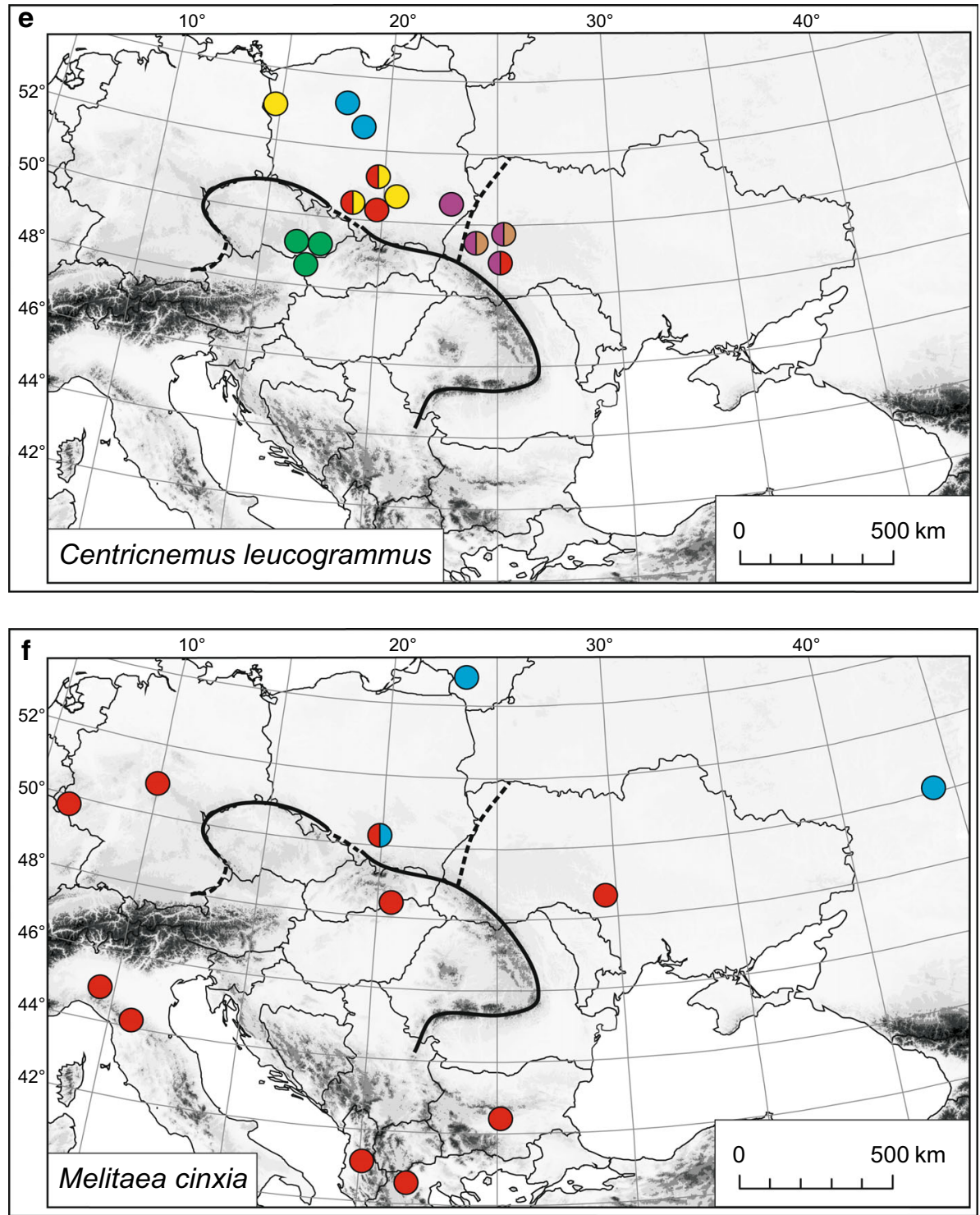

Fig. 2 continued

diversity or heterozygosity $0.25-0.5$ ) and (iii) "high" (haplotype diversity or heterozygosity above 0.5 ). It is important to note that some papers did not present the necessary primary values, and in these cases we tried to assign diversity to these three levels using other available information like patterns observed in phylogenetic trees/networks or results of implementation of other assignment algorithms, etc.

Character (2) Inter-regional distinctiveness-genetic differences among examined populations from any two of the three different regions established for the purposes of the 

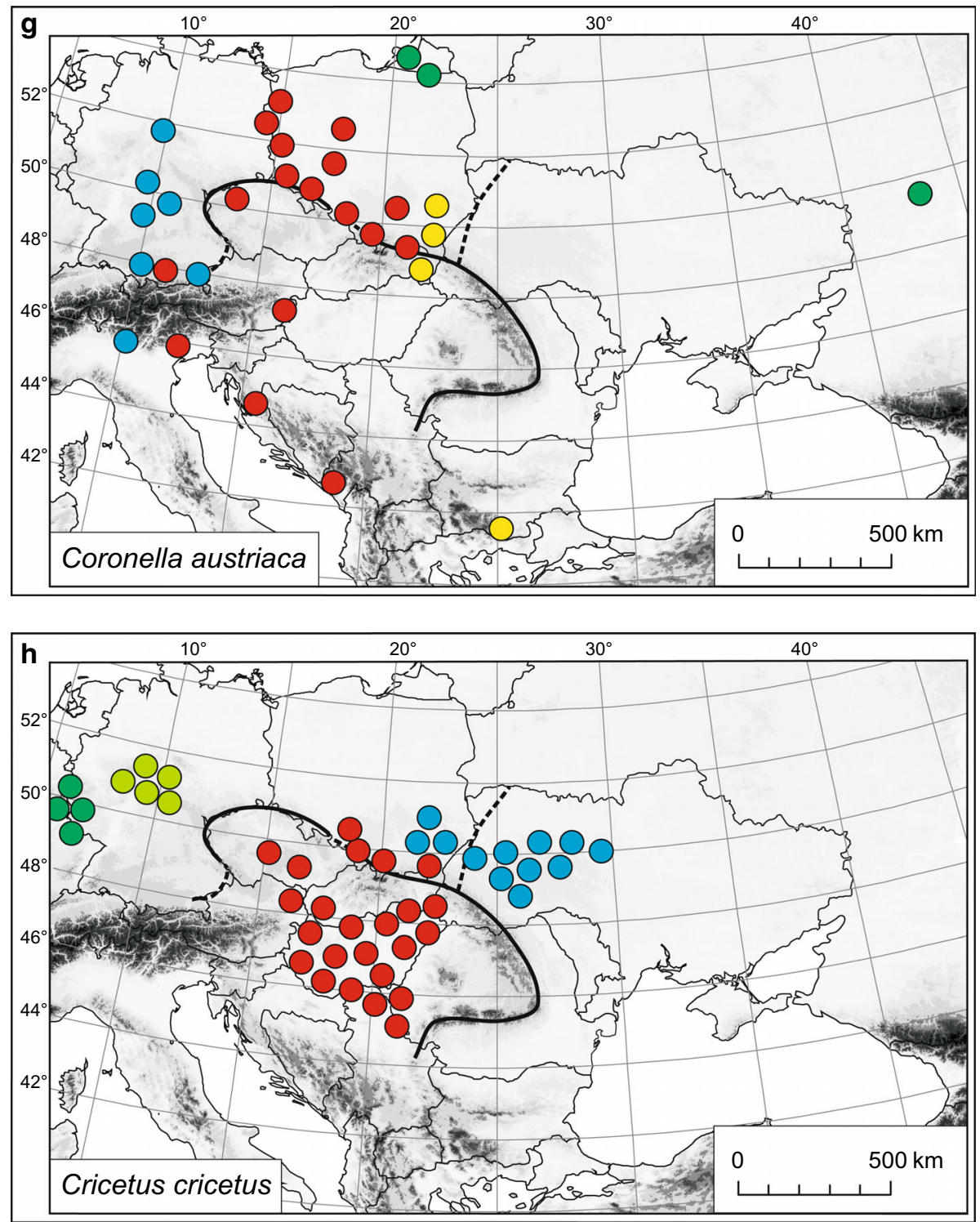

Fig. 2 continued

review (i.e. between Pontic, Pannonic and Northern regions), estimated (generalized) into three analogous categories (low, moderate, high) based mainly on values of fixation index $\mathrm{F}_{\mathrm{ST}}$ (or derivative measures as $\mathrm{G}_{\mathrm{ST}}$ or $\mathrm{R}_{\mathrm{ST}}$ ) and results of AMOVA and IBD-MT. For example, we assigned distinctiveness as: (i) "low" for $\mathrm{F}_{\mathrm{ST}}$ below 0.05, (ii) "moderate" when $\mathrm{F}_{\mathrm{ST}}$ was equal to $0.05-0.25$ and (iii) "high" for values above 0.25 , while for AMOVA the threshold values among groups (of populations) were $<10,10-50$ and $>50 \%$, respectively. As some taxa might comprise populations of low, moderate or 
high genetic diversity/distinctiveness depending on the area concerned, consequently the same taxon could be assigned to more than one of the presented classes.

Character (3) Distinct units around the Bohemian Massif-Carpathians arc-presence of distinct phylogenetic lineages (clades) or distinct genetic clusters between regions as described above. Presence of distinct units (yes/no) was directly or indirectly drawn from the available phylogenetic trees, haplotype/genotype networks and other genotype assignment algorithms' implementation results. Data examination for Character 3 was designed to verify two schemes: (i) (Character 3a) whether any region-specific units of the taxa were identified in the specified regions, and (ii) (Character $3 b$ ) whether all identified units were distinct among the specified regions. In the first scheme, we allowed for the presence of some genetic admixture between regions (presumably as the effect of past expansion or recent dispersion/migration), but the second scheme was applied strictly, as it described only "full genetic isolation". We used this data to count the frequencies of taxa expressing similar phylogeographic patterns in each of the selected categories.

The collected data were then analysed separately for animals and plants. We verified how many taxa show similar phylogeographic patterns in respect to all three characters described above.

\section{Results}

\section{Phylogeographic patterns of steppic species in Eastern Central Europe}

\section{Beetles}

The methods applied did not reveal any diversity among regional populations of Crioceris quatuordecimpunctata; for three others, Polydrusus inustus, Cheilotoma musciformis and Crioceris quinquepunctata, some local populations were also characterized by a lack of genetic variation (even in intra-population scale, generally not considered in the present paper). Two other beetles (Centricnemus leucogrammus and Coraebus elatus) showed low-to-moderate genetic diversity of populations, depending on their geographic localisation (usually higher diversity was observed in the eastern and southern parts of the range). The pattern of interregional distinctiveness was substantially different, as most of these species were characterized by high (C. musciformis and C. quatuordecimpunctata) or moderate-to-high (C. leucogrammus and $C$. elatus) distinctiveness of their populations from different regions (Fig. 2e). Only two species ( $P$. inustus and $C$. quinquepunctata) showed low genetic differentiation of even distant populations. Finally, most of these species expressed a significant divergence of phylogenetic lineages occurring in the Northern, Pontic and Pannonic regions. To the contrary, P. inustus and C. quinquepunctata expressed low genetic distinctiveness of populations. An interesting pattern was observed for three species (C. leucogrammus, C. elatus and C. quatuordecimpunctata) in northern Poland (the Kujawy Basin), where highly distinct phylogenetic lineages, different from all other Eastern Central European ones, were found. In at least one species (C. musciformis), the genetic divergence of populations suggests the existence of distinct taxonomic units (presumably subspecies) in southern Poland, Ukraine and the Pannonian Basin. 


\section{Butterflies}

Two butterflies (Polyommatus ripartii and Melitaea cinxia) were found to have low intraregional diversity, whereas two others (Maculinea alcon xerophilic ecotype and Maculinea arion) displayed low-to-moderate or high differentiation within regional populations (the values were higher in southern ones). Genetic distinctiveness of populations between regions varied as some species showed high levels of differentiation ( $M$. alcon and $M$. arion), whereas others displayed low or moderate levels ( $P$. ripartii and M. cinxia). Regarding the presence of distinct genetic units across the Carpathians and the Bohemian Massif, the studied butterflies generally did not show such patterns, with the exception of M. cinxia populations, which formed some distinct units (but not totally genetically isolated) when compared in north-south and east-south directions (Fig. 2f).

\section{Rodents}

Levels of intra-regional genetic diversities of rodent species and species-complexes differ; however all taxa comprise populations with an identified low genetic diversity. Only for three of these species (Spermophilus suslicus, Spermophilus citellus and Cricetus cricetus) there are populations known to have a high intra-regional diversity. They are always the ones located within continuous species range to the east (Ukraine) or south (the Pannonian Basin and adjacent areas of the Balkan Peninsula) of the Bohemian Massif-Carpathians arc. It is important to note that the other rodent taxa were studied using a limited sampling scheme for phylogenetic purposes, and therefore it was not possible to include these taxa in analyses on the population level. All the considered steppic rodents showed a high genetic distinctiveness at an interregional context (this parameter corresponded to the distinctiveness of species within Spalax spp. and within the Nannospalax leucodon superspecies, and to the presence of different species of Sicista subtilis agg.). Lastly, all of these taxa have different phylogenetic lineages inhabiting the Pontic and Pannonic regions. In Spalax spp. and in the N. leucodon superspecies, allopatric species were firstly described based on osteological characters and chromosomal differentiation and afterwards confirmed with use of molecular markers. In $S$. subtilis agg., distinct species were described (S. trizona within the Pannonic region and $S$. nordmanni within the Pontic region). Only S. suslicus and $C$. cricetus have current natural populations north of the Carpathians and the Bohemian Massif. These populations are distinct from the Ukrainian ones (especially for S. suslicus, and partially for $C$. cricetus, as its eastern lineage spans westward into eastern Poland) and from the Pannonic ones (although the Pannonic clade of $C$. cricetus spans northward into southern Poland, a distinct clade of this species is present in Germany (Fig. 2h); S. suslicus is replaced in Pannonia and south-eastern Central Europe by S. citellus, and both species are parapatric only in southern Ukraine and Moldova).

\section{Reptiles}

Coronella austriaca harbours a rather high genetic diversity in its regional populations, whereas the strictly south-eastern Dolichophis caspius, of the same snake family, is much less diverse genetically on a regional scale. Vipera ursinii and Vipera renardi, which form a species complex with multiple subspecies, have generally low genetic diversity at an intraregional scale; however when we consider complexes as a unit, the presence of distinct taxa in the Pontic region expresses a high diversity of populations from that large area. 


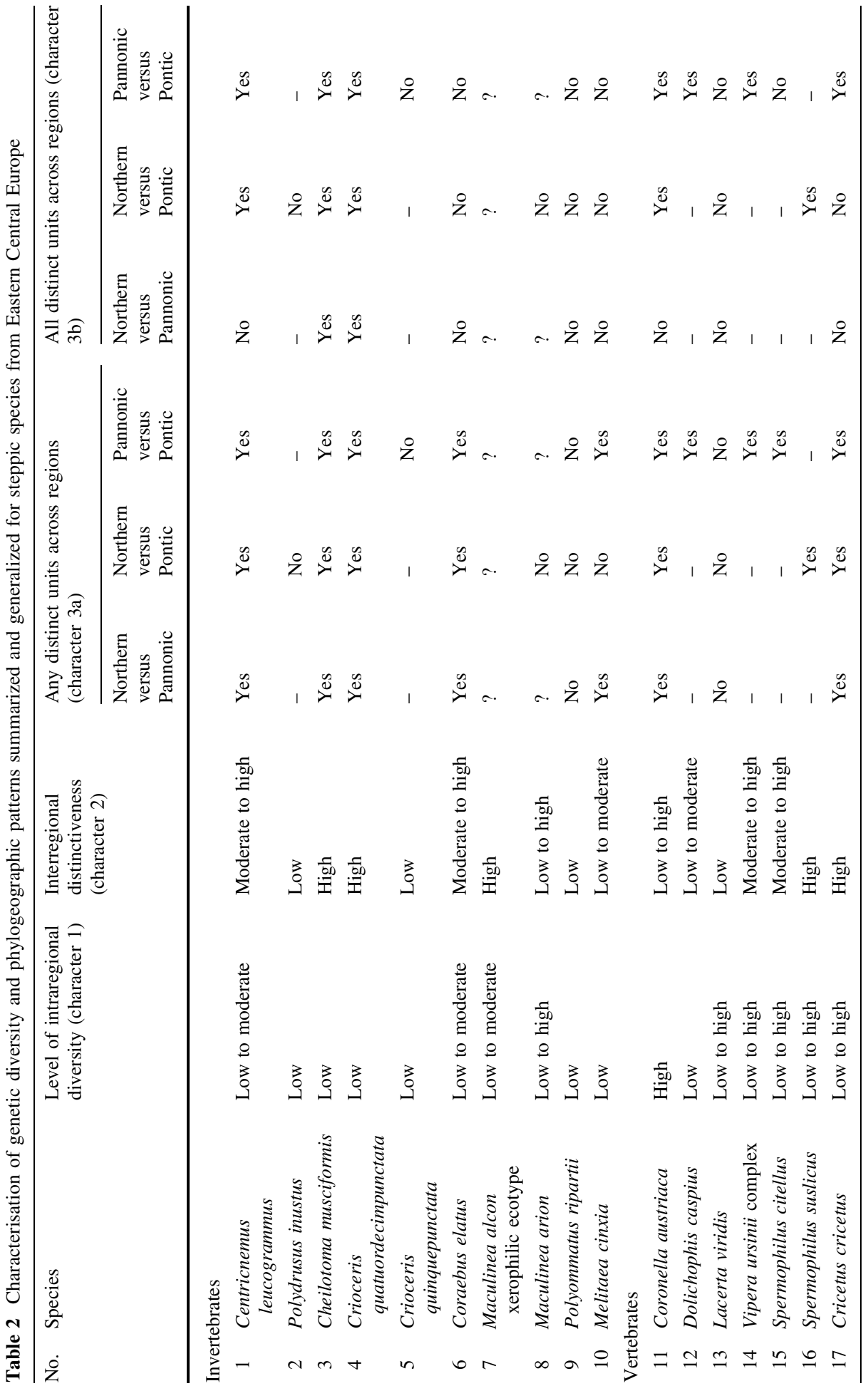




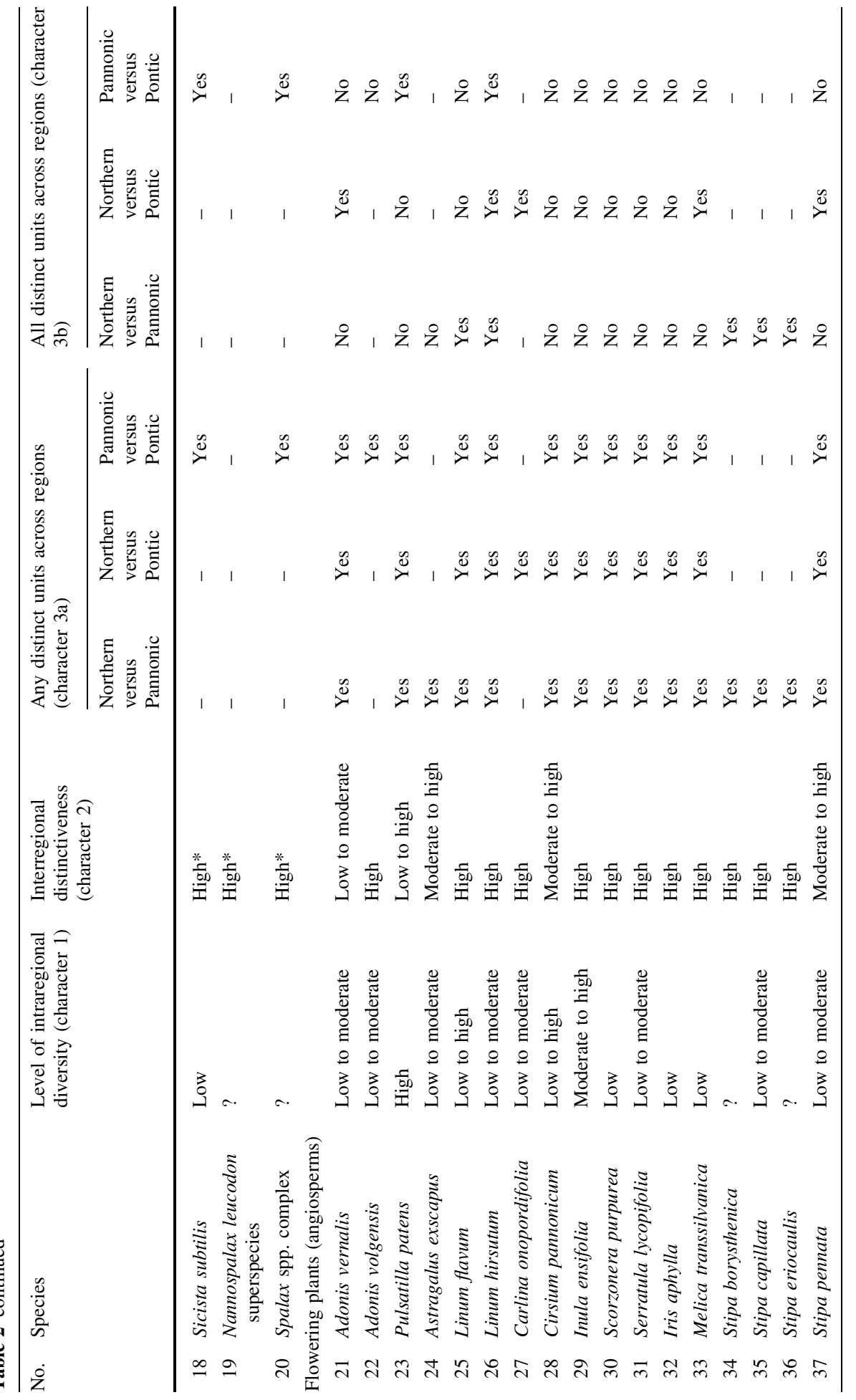




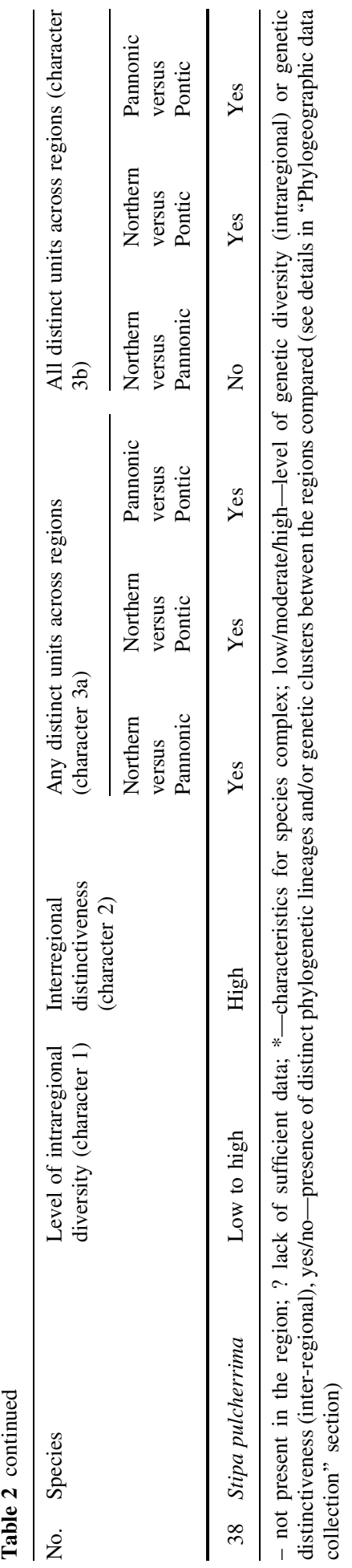

色) Springer 
Lacerta viridis has low genetic diversity across all populations studied. Regarding the interregional distinctiveness of populations, C. austriaca has distinct phylogenetic lineages in all three regions (Northern, Pontic and Pannonic) (Fig. 2g), but the Carpathians are not an effective barrier in this case, as this species inhabits xeric grasslands and stony slopes in mountainous areas, as well. For D. caspius and the $V$. ursinii complex, species which are absent in the Northern region, distinct phylogenetic lineages were found in the Pontic and Pannonic regions. On the contrary, L. viridis has an unstructured mitochondrial diversity in Eastern Central Europe, albeit highly distinct phylogenetic lineages were found in the Mediterranean Basin including the sibling species, L. bilineata. At the same time, L. viridis has a highly reduced genetic diversity in its marginal populations (based on microsatellite genotyping). Genetic structure of $L$. viridis suggests that it is not a "real" steppic but rather a "Ponto-Mediterranean" species.

\section{Flowering plants}

The intra-regional genetic diversity of plant species and species complexes is not homogeneous, and it is often dependent on the situation of the examined populations in respect to the entire species range. Within the continuous part of the range, these plants harbour lowto-moderate genetic diversity. This concerns mainly populations from the Pontic and Pannonic (including the northern Balkan Peninsula) regions, whereas among populations located on the edge of the species range or in isolated, peripheral localities (like in Poland or Germany), the genetic diversity is conspicuously higher. Such a situation could be observed, for example, in Scorzonera purpurea, Serratula lycopifolia and Stipa pennata. The lowest diversity values were observed between populations closest to or within the continuous part of the range (the Pontic region), whereas those from the Northern and Pannonic regions were more diverse. Regarding the inter-regional distinctiveness of populations, almost all of the plants examined were assigned to high or moderate-to-high differentiation level groups. This distinctiveness is especially visible due to the presence of different genetic clusters in all three of the regions around the Carpathians and the Bohemian Massif region. The exceptions were Pulsatilla patens, which had a low diversity between some of its Northern and Pontic populations, and Adonis vernalis, which had a low diversity within the Pontic and moderate within Pannonic and Northern regions. A somewhat more complicated situation was found in the case of Astragalus exscapus, where variability of several parallel markers (allozymes) is presented, some of them displaying divergent patterns (e.g. ADH showing much higher differentiation within the peripheral Northern (German) populations than within the more "central" Pannonic (Bohemian, Moravian and lower Austrian) ones, while for AAT2 or GPI the situation is quite the opposite).

A significant differentiation of populations was also often observed within these regions, probably caused by long-term isolation. Within the Northern region, distinct clusters were identified, e.g. in the Małopolska Upland versus the Lviv-Lublin Upland for Carlina onopordifolia and Linum flavum (Fig. 2a). Similarly, distinct clusters were found for the German Uplands versus most of eastern Poland versus the remaining part of the northern range for Iris aphylla (Fig. 2c), and in the German Uplands versus the lowlands of northern Germany versus northern Poland for Scorzonera purpurea (Fig. 2d). Within the Pannonic region, such clusters were found for Bohemia-Moravia versus the Pannonian Basin vs. Transylvania, e.g. in Cirsium pannonicum, Linum hirsutum, S. purpurea, Adonis vernalis and Stipa pulcherrima. Similarly, both Adonis volgensis and P. patens were characterized by lineages in the Pannonian Basin that were isolated from their steppic counter-populations in the Pontic region (Fig. 2b). 


\section{Genetic intra-regional diversity and inter-regional differentiation of steppic taxa populations}

Nearly all (94\%) of the examined animal taxa (17 out of 18 for which respective data were available) displayed low genetic diversity on an intra-regional scale, at least for some of their populations. Similarly, $94 \%$ of the plants (15 out of 16 for which respective data were available) have some or all of their populations characterised by low diversity. Moreover, in only $33 \%$ of animal taxa (six), some or all populations expressed high diversity. In plants, highly diverse populations were found in $38 \%$ of taxa (six) (Table 2). Usually, the genetic diversity of the steppic animals increased to the east and to the south, as the Pontic and Pannonic regions sustained populations much more genetically diversified than the Northern region (Poland and Germany). This pattern was visible even within the Pannonic region, as Bohemia sometimes possessed only single genetic variant, opposed to the parts situated more towards the east and south. To the contrary, in plants, many taxa expressed the opposite pattern of genetic diversity. The majority of their most diverse populations are in the Northern region, and only a few are in the Pannonic or Pontic ones.

Regarding the genetic distinctiveness of populations on an inter-regional scale, most steppic taxa were structured geographically: $70 \%$ of animals (14 out of 20) and $94 \%$ of plants (17 out of 18). Highly distinct phylogenetic lineages and/or genetic clusters were identified in all, or at least some, distant areas occupied by steppes or other types of xeric grasslands in Eastern Central Europe (including eight taxa of animals and 14 taxa of plants that had a high level of differentiation throughout their entire ranges in the area). On the other hand, $35 \%$ of animals (7 taxa) and $11 \%$ of plants (2) had a low distinctiveness of population between at least some regions (but only 4 animal taxa had a low genetic differentiation among all regions of study) (Table 2).

The most interesting phylogeographic patterns arose when the presence of distinct genetic units (phylogenetic lineages or genetic clusters) were analysed between different sides of the Bohemian Massif-Carpathian arc.

The Pannonic and Northern regions were found to sustain distinct units in $78 \%$ of the animal taxa (7 out of 9 taxa present in both regions) in the 3a character (Table 2), or in $22 \%$ of them (2) when counted according to the $3 \mathrm{~b}$ character. For plants, these numbers were $100 \%$ (all 16 taxa) and $38 \%$ (6), respectively (Table 2).

Between the Pontic and Northern regions, distinct units were found in $58 \%$ of the animal taxa (7 out of 12) in the 3a character, or in $50 \%$ (6 taxa) when counted according to $3 \mathrm{~b}$ character. Analogous values for plants (a comparison between the Pontic and Northern regions) were $100 \%$ (all 13 taxa) and $46 \%$ (6), respectively (Table 2).

Separate genetic units between the Pannonic and Pontic regions were present in $80 \%$ of the animal taxa (12 out of 15 taxa) were at least partly separated, whereas $60 \%$ of them (9) were characterised by full genetic isolation between these regions (Table 2). For plants, these numbers were $100 \%$ (all 13 taxa) and only $23 \%$ (3), respectively (Table 2).

\section{Discussion}

The genetic and phylogeographic data of the populations presented in this review clearly show that steppic species generally neither follow an east-to west, nor a south-to-north decreasing phylogeographic pattern. Therefore, we can exclude both a relatively recent 
east-to-west immigration hypothesis and the classical north-south "contraction-expansion" paradigm regularly observed in temperate species (Taberlet et al. 1998; Hewitt 1999, 2000; Petit et al. 2003; Schmitt 2007). The genetic diversity and distinctiveness of steppic populations is rather similar to the pattern observed in arctic-alpine taxa (e.g. Schoenswetter et al. 2005; Varga and Schmitt 2008; Schmitt 2009). The geographic structure of genetic characteristics hint at a more complex history in the western part of the steppic biom. Cold-tolerant steppic species seem to have been much more widely distributed and probably more abundant during cold periods than during interglacials (including the current one) (Stewart et al. 2010; Varga 2010). It is often postulated that in Eastern Central Europe, steppe-related species of animals (rodents) and plants (e.g. Astragalus exscapus) were distributed more widely during glacial periods than during interglacials (Pawłowska 1966; Becker 2012; Sommer and Nadachowski 2006). They may have occupied the extensive areas between the ice sheet in the lowlands of central and northern Europe and mountain ranges like the Alps, the Bohemian Massif and the Carpathians. This is probably a consequence of the type of glacial zonation being fundamentally different from the recent (interglacial) one. The major dynamic elements of this glacial zonation were as follows: (i) the fragmentation of the nemoral and boreal forest zone; (ii) the expansion of diverse continental meadow steppic elements during the cool, but not extremely cold, phases of glaciations; (iii) the expansion of continental cold steppe elements in the cryoxeric phases, followed by postglacial fragmentation; (iv) the establishment of manifold ecotones at the junctions of zonal and intrazonal continental habitat types (Varga 2010; Schmitt and Varga 2012). Steppic species were probably also widespread in the Pannonian Basin (Magyari et al. 2010).

\section{A history of steppic species in Eastern Central Europe}

The existence of steppes and steppic populations during Pleistocene glaciations within the Pannonian Basin and the Pontic area has been confirmed by paleontological and chorological data (Willis and Van Andel 2004). Both areas were never glaciated and were localised relatively far from the ice sheet, even during the Sanian/Elsterian glaciation, which extended most to the south (Ehlers and Gibbard 2004). There is a considerable body of evidence suggesting that cold steppes and forest steppe associations existed during Pleistocene glaciations in the Pannonian Basin, and that more eurythermic species could have survived the last glacial maximum (LGM) at least in favourable microsites (Willis et al. 2000; Jankovská and Pokorný 2008; Magyari et al. 2010, 2014). On the other hand, the existence of populations of steppic species north of the Alps, the Bohemian Massif and the Carpathians is more controversial. This area was only once fully glaciated (the Sanian/ Elsterian glaciation, 730,000-430,000 years ago), whereas during following ice periods, only some parts of these areas were under the ice sheet. In particular, uplands in central and southern Germany and south-eastern Poland have not been glaciated since the Sanian/ Elsterian (Lindner et al. 2006; Wysota et al. 2009). Even during that extensive glaciation, these uplands were not fully ice-covered, or perhaps some areas survived as nunataks within the ice sheet (Lindner et al. 2006; Lewandowski 2011). Consequently, these uplands could have been temporarily covered by steppe vegetation during cryoxeric phases of at least some glacials. This hypothesis finds support in phylogeographic data which shows that these uplands harbour distinct phylogenetic lineages or genetic clusters of several steppic species (e.g. beetles: Centricnemus leucogrammus, Cheilotoma musciformis, Crioceris quatuordecimpunctata, hamster Cricetus cricetus and plants: Cirsium pannonicum, Inula ensifolia, Linum flavum, L. hirsutum and Stipa pulcherrima). This distinctiveness is 
so high compared to other populations in the east and south that it is unlikely to have developed simply during a Holocene expansion. Some of these are probably remnants of much larger populations of species that were widely distributed during glaciations and populations of which are presently isolated by mountain ranges and other areas covered by unfavourable natural habitats (forests). Another explanation is that their distribution is now conditioned by land that has been transformed by humans (in both favourable, e.g. agricultural, and unfavourable ways, e.g. urbanized, roads, railways).

It is challenging to estimate when these species expanded into the areas north of the Bohemian Massif-Carpathians arc, but their current populations must be younger than 430 000 years (from the end of the Sanian/Elsterian glaciation) (Lindner et al. 2006). A few dating efforts of divergence and expansion times suggest that these northern populations could have indeed originated 380,000-150,000 years ago (Centricnemus leucogrammus) or 147,000-85,000 years ago (Cricetus cricetus) and expanded 280,000-110,000 years ago (C. leucogrammus) or 115,000-10,000 years ago (C. cricetus) (Neumann et al. 2005; Kajtoch et al. 2009). Spans of these dating suggest that these events took place during Oder and Warta/Riss glaciations (for C. leucogrammus) or Vistulian/Würm glaciation (for $C$. cricetus). These datings of divergence and subsequent expansion of distinct phylogenetic lineages probably differ for other species. They would depend, for example, on the species' mobility (by physical movement or seed dispersal), probability of survival in small areas with a limited population size and tolerance to climatic and environmental changes. Butterflies and some plants with easy seed dispersal may have expanded (at least to some of the existing stations) across northern areas in relatively recent times (after the LGM, 26,000-19,000 years ago), whereas some wingless beetles or plants with heavy seeds would have needed to be present north of the Carpathians-Bohemian Massif earlier and survive in situ to the present time (if they had expanded after the LGM, there would not likely be enough time for them to settle all these distant areas and form distinct genetic units).

\section{Current "warm stage" refugia of steppic taxa}

Consequently the uplands of southern Germany and south-eastern Poland should be considered as additional "warm stage" refugia for steppic species, apart from the presumed major refugia in the Pontic and Pannonic regions (Stewart et al. 2010; Varga 2010). Moreover, phylogeographic data for several species suggests that the Lublin-Lviv Upland at the Polish-Ukrainian border is probably a transient zone between genetic units characteristic for eastern populations (from Ukraine) and those known in the uplands of southern Poland (Centricnemus leucogrammus, Cricetus cricetus, Inula ensifolia). It could also be a refugium for some unique genetic clusters (like in Carlina onopordifolia). The discovery of unique phylogenetic lineages as far north as the Kujawy Basin $(C$. leucogrammus, Crioceris quatuordecimpunctata, Coraebus elatus) or eastern Poland and central Germany (Iris aphylla) is considered to be of high importance as these areas were deglaciated only 18,000-12,000 years ago (Wysota et al. 2009). Existence of steppic populations in the Northern region before the Holocene could also explain a high genetic diversity of some plant species-higher even than observed in "core" populations in Pontic and Pannonic regions. This high diversity could reflect substructuring of steppic populations in fragmented xeric grasslands in Germany and Poland. Contrary, in Pannonic and Pontic regions populations were (and locally are) interconnected (Sutcliffe et al. in press) so they could be more uniform genetically. Interesting is that this phenomenon apparently concerns only (the studied) plants but not (the studied) animals, in which 
marginal, isolated populations generally were less diverse than these from the continuous parts of species' ranges.

The reviewed phylogeographic patterns suggest a complex history and structured phylogeography of the eastern (Pontic) and southern (Pannonic) refugia. Several areas in the Pontic region sustain diverse phylogenetic lineages: (i) the Podolian Upland (western Ukraine), (ii) Dobrogea (eastern Romania), (iii) Crimea, (iv) eastern Ukraine and southern Russia (exemplary taxa with distinct lineages in some of these areas: Coraebus elatus, Spermophilus suslicus, Sicista subtilis agg., Coronella austriaca, Vipera ursinii complex, Adonis vernalis, A. volgensis, Scorzonera purpurea and Stipa pulcherrima). In the Pannonic region, distinct refugia were identified: (i) Moravia-Bohemia (an exemplary species with a distinct lineage in this area is Cirsium pannonicum); (ii) the Pannonian Basin (Linum flavum, L. hirsutum); (iii) the Transylvanian Basin (Adonis volgensis and the butterfly Kretania pylaon sephirus; Pecsenye et al. 2007) and (iv) the northern Balkan Peninsula (taxa with distinct units between the northern Balkan Peninsula and the Pannonian Basin are Spermophilus citellus and the Nannospalax leucodon superspecies). The barrier formed by the Eastern Carpathians to some of the analysed taxa (S. trizona, A. volgensis, Pulsatilla patens) is especially interesting. These taxa, with a centre of distribution in the Pontic area, are apparently more diverse in the Pannonian Basin (together with the Transylvanian Basin) than in neighbouring Dobrogea or south-eastern Ukraine. Development of distinct units between Pontic and Pannonic regions was also predicted by the distribution modelling of the steppic butterfly Melitaea ornata in which the Pannonian, Eastern Balkanic and Pontic population groups can be derived from distinct refugia (Tóth and Varga 2011; Tóth et al. 2012, 2014). Preliminary analyses suggest (W. Paul, in prep.) that a similar pattern (i.e. conspicuous genetic separation between Pontic and Pannonic lineages) can be observed in case of another steppic vascular plant, Campanula sibirica. Unfortunately, the inavailability of (published) full genetic data prevented regular inclusion of these species into the present review.

Some of the steppic species, especially those with ranges confined to the Balkan Peninsula and the Pannonian Basin, could have a different origin compared to species which could be derived from former cold steppes. These species (or sibling taxa in species complexes) have ranges often stretching across Anatolia, the Balkan Peninsula and the Pannonian Basin. The occurrence of these taxa in the Pannonian Basin's steppic habitats could be related to the more ancient expansion of some xeric elements from Anatolia (where steppes and other types of xeric grasslands also exist) into south-eastern Europe. An investigation of this pattern needs more phylogeographic data from species inhabiting Anatolia (and possibly also the Caucasus), the Balkan Peninsula and the Pannonian Basin, but this is out of the scope of this review.

\section{Prospects beyond steppic species}

Our conclusions might not be restricted to steppic species in the strict sense (related to xeric grasslands), but could possibly be extended to some other taxa related to more mesoor even hygrophilous continental meadow steppes (like the plants Bistorta affinis, Sanguisorba officinalis and Dianthus superbus and the insects Arcyptera fusca, Gampsocleis glabra, Tettigonia caudata, Aricia artaxerxes, Maculinea spp. and Melitaea spp.; Varga 2002). Such species are and also were widely co-distributed with more cold- and xericadapted steppic species during glaciations and probably experienced similar range contractions during interglacials. This hypothesis however needs phylogeographic investigation, as appropriate analyses are available only for the butterflies Lycaena helle (Habel 
et al. 2014) and the Boloria (Proclossiana) eunomia (Nève et al. 2000). This hypothesis is also supported by the phylogeography of two ecotypes (xeric- and hygrophilous) of the steppic beetle Coraebus elatus (Kajtoch et al. 2014b).

\section{Conservation implications}

From a conservation point of view, the factor of major importance is the low genetic diversity among (and usually also within) many (local) populations. This genetic depletion of steppic populations could be explained in two ways, which are not mutually exclusive. For the populations that displayed a reduced genetic diversity and lack of differentiation from the main area, this reduced genetic diversity can be explained either by the effect of drift (i.e. random change in the frequency of alleles in a population) or by founder effect (i.e. establishment of local populations by a limited number of genetically closely related individuals). For populations with a reduced genetic diversity and significant differentiation from other regions, a possible explanation is that the long-existing local populations might have undergone bottle-necks, which could have depauperated genetic diversity while providing a chance for local genotypes to sweep through the surviving population. The majority of phylogeographic patterns described in this paper support the second scenario. Regardless of the reason, low genetic diversity could have a serious impact on the probability of the survival of these populations as limited variation in genes could lead to further population decline and extinction (Frankham et al. 2002). There are known examples of highly threatened or even endangered populations of steppic animals and plants with low genetic diversity (e.g. Cheilotoma musciformis, Kajtoch et al. 2013; Spermophilus suslicus, Biedrzycka and Konopiński 2008, Carlina onopordifolia and Linum hirsutum, Cieślak 2014).

Another issue of conservational importance is the presence of distinct genetic units (phylogenetic lineages and/or genetic clusters) in different regions occupied by steppic species in Eastern Central Europe. As we described in the present paper, many steppic species or species complexes, both animals and plants, showed substantial differentiation in their populations from different regions (defined for purposes of this review). This genetic distinctiveness was interpreted in many of the examined steppic organisms as a presence of different "evolutionarily significant units" and/or "management units" (Moritz 1994; Vogler and Desalle 1994). These units should be treated independently when planning conservation strategies and managing populations or habitats. Conservation actions are crucial, as distinct evolutionary units often have different environmental and ecological requirements, and the mixing of individuals from diverse lineages (e.g. during translocation or introduction actions) could be harmful for the fitness of progenies and the survival of populations (outbreeding depression: Frankham et al. 2002). Lastly, these evolutionary units could also have taxonomic value (e.g. identification of taxonomic structure like in Sicista subtilis, Cserkész et al. 2015a, b; the "near to extinction" taxa of the Nannospalax leucodon superspecies, Németh et al. 2013, species within the Vipera ursinii complex, Ferchaud et al. 2012; Gvozdik et al. 2012; Zinenko et al. 2015, or presumable subspecies such as in Cheilotoma musciformis and Coraebus elatus; Kajtoch et al. 2013, 2014a, b).

Obviously, it is impossible to protect all populations of all steppic species which show substantial genetic distinctiveness (it would be even not possible to investigate all these populations!). The priority in steppic organism conservation should be to protect those areas that are characterized by highest biodiversity and simultaneously sustain distinct genetic units of some selected (flagship, keystone) species. A general list of such areas is 
presented above, but more comprehensive and detailed studies are needed to select particular "hot spots" where protected areas need to be designed.

Because steppic habitats, communities and populations in Eastern Central Europe are highly threatened, genetic factors (like these identified based on phylogeographic analyses here) should be taken into consideration for the conservation of these species and in managing steppes and xeric grasslands.

\section{Conclusions}

Based on the results and the above part of the discussion, in respect to the hypotheses enumerated in the "Introduction" section it may be stated, that (see also Information Box 2):

1. The steppic taxa, their similar ecological demands and biogeographical features notwithstanding, do not show a uniform phylogeographic pattern. However, some common characteristics include: (i) generally lower intraregional than interregional genetic diversity of populations (with some species showing very low or lack of genetic variability on a local scale); (ii) presence of distinct evolutionary units in each of three defined "steppic regions" (Pannonian, Pontic and Northern) with (iii) substantial phylogeographic substructuring of populations within regions (usually inhabiting currently isolated areas rich in steppic habitats).

2. Almost all steppic taxa or their groups show phylogeographic patterns generally congruent with that defined for cold-adapted (arctic-alpine) species, that is interglacial-contraction and glacial-expansion dynamic (opposite to the phylogeographic paradigms known for temperate-related species).

3. In most cases, genetic differences, if any, are clearly connectable to mountain chains, which have seemingly acted as important barriers for the migration and/or genetic contact of steppic plants and animals.

Information Box 2 Major conclusions drawn from phylogeographic patterns observed in steppic plants and animals

Generally low genetic diversity of animal populations in intra-regional scale, especially in marginal populations, which has serious conservation implications for survival of local populations

Varied genetic diversity of plant populations in intra-regional scale with unexpected lower diversity in core populations of some species in Pontic region

Substantial genetic distinctiveness of populations inter-regionally and for some taxa also within regions (substructuring of populations caused by their history and current habitat fragmentation)

High share of species with distinct genetic units across Bohemian Massif and Carpathians arc-presence of distinct evolutionary significant units in each of three major areas: Northern, Pannonic and Pontic

There is no east-to-west decreasing genetic diversity and distinctiveness, which should be expected in case of a recent east-to-west migration scenario

Confirmation that Pontic and Pannonic regions were being settled by steppic species throughout cold or cool phases of the Upper Pleistocene and there are current "warm stage refugia" for steppic species

Proof that at least some steppic species must have persisted in situ also north of the CarpathiansBohemian Massif-Alps arc at least since Sanian/Elsterian glaciation (430,000 years ago), which contradicts the statement of the exclusively human origin of xeric grasslands in Poland and Germany

Urgent necessity to identify "hot spot" areas, which sustain high biodiversity and distinct evolutionary units of steppic species, for effective protection of steppic habitats and populations 
4. Phylogeographic patterns of steppic species do not follow the current species diversity, i.e. apparently there is no east-to-west decreasing genetic diversity and distinctiveness that should be expected in case of a recent east-to-west immigration scenario. Quite the contrary, the present genetic pattern hint at a more complex phylogeographic history of steppic species at their present-day western distribution edge.

5. In several cases (e.g. Cheilotoma musciformis, Melitaea cinxia, Coronella austriaca, Cricetus cricetus, Linum flavum or Scorzonera purpurea), has been found genetic evidence for the existence of hitherto disregarded extrazonal microrefugia. Interestingly, many of the examined species show distinct evolutionary units not only in the Pontic and Pannonian regions, where refugia for steppic taxa have already been considered (Stewart et al. 2010; Varga 2010), but also in the Northern region. This indicates the presence of extrazonal microrefugia also to the north of the Bohemian Massif-Carpathians arc. Moreover, the presence of genetic differences without any apparent geographic barriers within the Northern region in approx. $60 \%$ of examined animal and all examined plant taxa may reflect the genetic signature of several separate migrational waves here.

Acknowledgments This work was based on research projects funded by: Polish Ministry of Higher Education and Science (N N303 311137-D.K, Ł.K. and M.A.M., N N303 612238-Ł.K., D.K. and M.A.M., N N304 362738-W.P. and E.C.; N N304 154633-E.C.; N N304 300940 -E.C.); National Science Centre, Poland (UMO-2011/01/B/NZ8/01491-D.K, Ł.K. and M.A.M.), and partly from the statutory funds of the W. Szafer Institute of Botany PAS-E.C. and W.P. The support of the Hungarian National Research Fund to Z.V. (OTKA K-84071) and G.S. (OTKA PD109686) is greatly appreciated. The work of G.S. was supported by the Bolyai Scholarship of the Hungarian Academy of Sciences.

\section{Compliance with ethical standards}

Conflict of interest The authors declare that they have no conflicts of interest.

Open Access This article is distributed under the terms of the Creative Commons Attribution 4.0 International License (http://creativecommons.org/licenses/by/4.0/), which permits unrestricted use, distribution, and reproduction in any medium, provided you give appropriate credit to the original author(s) and the source, provide a link to the Creative Commons license, and indicate if changes were made.

\section{References}

Ashcroft MB (2010) Identifying refugia from climate change. J Biogeogr 37:1407-1413

Bajc M, Čas M, Ballian D, Kunovac S, Zubić G, Grubešić M, Zhelev P, Paule L, Kraigher H (2011) Genetic differentiation of the Western Capercaillie highlights the importance of South-Eastern Europe for understanding the species phylogeography. PLoS ONE 6:1-15

Banaszek A, Jadwiszczak KA, Ratkiewicz M, Ziomek J, Neumann K (2010) Population structure, colonization processes and barriers for dispersal in the common hamster Cricetus cricetus (L.) populations in Poland. J Zool Syst Evol Res 48:151-158

Banaszek A, Jadwiszczak KA, Ziomek J (2011) Genetic variability and differentiation in the Polish common hamster (Cricetus cricetus L.): genetic consequences of agricultural habitat fragmentation. Mamm Biol 76:665-671

Banaszek A, Ziomek J, Jadwiszczak KA, Kaczyńska E, Mirski P (2012) Identification of the barrier to gene flow between phylogeographic lineages of the common hamster Cricetus cricetus. Acta Theriol 57:195-204

Bartha LA, Sramkó G, Volkova PA, Surina B, Ivanov AL, Banciu HL (2015) Patterns of plastid DNA differentiation in Erythronium (Liliaceae) are consistent with allopatric lineage divergence in Europe across longitude and latitude. Plant Syst Evol 301:1747-1758

Becker T (2012) Die Steppenreliktart Astragalus exscapus-eine Schlüsselart der Steppenreste Mitteleuropas? In: Baumbach $\mathrm{H}$, Pfützenreuter S (eds) Steppenlebensräume Europas-Gefährdung, 
Erhaltungsmaßnahmen und Schutz. Thüringer Ministerium für Landwirtschaft, Forsten, Umwelt und Naturschutz, Erfurt, pp 69-90

Bennett KD, Provan J (2008) What do we mean by 'refugia'? Quat Sci Rev 27:2449-2455

Bereczki J, Pecsenye K, Peregovits L, Varga Z (2005) Pattern of genetic differentiation in the Maculinea alcon species group (Lepidoptera, Lycaenidae) in Central Europe. J Zool Syst Evol Res 43:157-165

Bereczki J, Tóth JP, Sramkó G, Varga Z (2014) Multilevel studies on the two phenological forms of Large Blue (Maculinea arion) (Lepidoptera: Lycaenidae). J Zool Syst Evol Res 52:32-43

Berman D, Alfimov A, Kuzmina S (2011) Invertebrates of the relict steppe ecosystems of Beringia, and the reconstruction of Pleistocene landscapes. Quat Sci Rev 30:2200-2219

Bhagwat SA, Willis KJ (2008) Species persistence in northerly glacial refugia of Europe: a matter of chance or biogeographical traits? J Biogeogr 35:464-482

Biedrzycka E, Konopiński M (2008) Genetic variability and the effect of habitat fragmentation in spotted suslik Spermophilus suslicus populations from two different regions. Conserv Gen 9:1211-1221

Böhme MU, Moravec J (2011) Conservation genetics of Lacerta viridis populations in the Czech Republic (Reptilia: Lacertidae). Acta Soc Zool Bohem 75:7-21

Böhme MU, Schneeweiss N, Fritz U, Schlegel M, Berendonk TU (2007a) Small edge populations at risk: genetic diversity of the green lizard (Lacerta viridis viridis) in Germany and implications for conservation management. Conserv Gen 8:555-563

Böhme MU, Fritz U, Kotenko T, Džukić G, Ljubisavljević K, Tzankov N, Berendonk TU (2007b) Phylogeography and cryptic variation within the Lacerta viridis complex. Zool Scr 36:119-131

Braun-Blanquet J (1961) Die inneralpine Trockenvegetation. Fischer, Stuttgart

Cieślak E (2013) Variation and genetic structure of Serratula lycopifolia populations (Vill.) Kern. (Asteraceae) in Poland and adjacent regions. Acta Soc Bot Pol 82:67-75

Cieślak E (2014) Phylogeography of Pontic-Pannonian species in Central Europe. Pol Bot Stud 30:1-53

Cremene C, Groza G, Rakosy L, Schileyko A, Baur A, Erhardt A, Baur B (2005) Alterations of steppe-like grasslands in Eastern Europe: a threat to regional biodiversity hotspots. Conserv Biol 19:1606-1618

Cserkész T, Aczél-Fridrich Z, Hegyeli Z, Sugár S, Czabán D, Horváth O, Sramkó G (2015a) Rediscovery of the Hungarian birch mouse (Sicista subtilis trizona) in Transylvania (Romania) with molecular characterisation of its phylogenetic affinities. Mammalia 79:215-224

Cserkész T, Rusin M, Sramkó G (2015b) An integrative systematic revision of the European southern birch mice (Rodentia: Sminthidae, Sicista subtilis group). Mammal Review. doi:10.1111/mam.12058

Dengler J, Janišová M, Török P, Wellstein C (2014) Biodiversity of Palaearctic grasslands: a synthesis. Agric Ecosyst Environ 182:1-14

Doniţa N, Karamyševa ZV, Borhidi A, Bohn U (2003) L-Waldsteppen (Wiesensteppen im Wechsel mit sommergrünen Laubwäldern) und Trockenrasen im Wechsel mit Trockengebüschen. In: Bohn U, Neuhäusl R, Gollub G, Hettwer C, Neuhäuslová Z, Raus T, Schlüter H, Weber H (eds) Karte der natürlichen Vegetation Europas/Map of the Natural Vegetation of Europe. Maßstab/Scale $1: 2500$ 000. Erläuterungstext. Landwirtschaftsverlag, Münster, pp 426-440

Durka W, Nossol C, Ruprecht E, Wagner V, Welk E, Hensen I (2013) Extreme genetic depauperation and differentiation of both populations and species in Eurasian feather grasses (Stipa). Plant Syst Evol 299:259-269

Ehlers J, Gibbard P (2004) Quaternary glaciations-extent and chronology. Elsevier, London

Fekete G, Molnár Z, Magyari E, Somodi I, Varga Z (2014) A new framework for understanding Pannonian vegetation patterns: regularities, deviations and uniqueness. Comm Ecol 15:12-26

Ferchaud AL, Ursenbacher S, Cheylan M, Luiselli L, Jelic D, Halpern B, Major A, Kotenko T, Keyans N, Behrooz R, Crnobrnja-Isailovic J, Tomovic L, Ghira I, Ioannidis Y, Arnal V, Montgelard C (2012) Phylogeography of the Vipera ursinii complex (Viperidae): mitochondrial markers reveal an east-west disjunction in the Palaearctic region. J Biogeogr 39:1836-1847

Frankham R, Ballou JD, Briscoe DA (2002) Introduction to conservation genetics. Cambridge University Press, Cambridge

Galarza JA, Mappes J, Valkonen JK (2015) Biogeography of the smooth snake (Coronella austriaca): origin and conservation of the northernmost population. Biol J Linn Soc 114:426-435

González-Sampériz P, Leroy S, Carrión J, Fernández S, García-Antón M, Gil-García M, Uzquiano P, Valero-Garcés B, Figueiral I (2010) Steppes, savannahs, forests and phytodiversity reservoirs during the Pleistocene in the Iberian Peninsula. Rev Palaeobot Palynol 162:427-457

Gvozdik V, Jandzik D, Cordos B, Rehak I, Koltik P (2012) A mitochondrial DANN phylogeny of the endangered vipers of the Vipera ursinii complex. Mol Phylogenet Evol 62:1019-1024

Habel JC, Meyer M, Schmitt T, Husemann M, Varga Z (2014) The molecular biogeography of the Violet Copper Lycaena helle. In: Habel JC, Meyer M, Schmitt T (eds) Jewels in the mist, a synopsis on the endangered Violet Copper butterfly Lycaena helle. Pensoft, Sofia, pp 111-124 
Hadid Y, Nemeth A, Snir S, Kázmér M, Major A, Mezhzherin S, Rusin M, Coşkun Y, Nevo E (2012) Is evolution of blind mole rats determined by climate oscillations? PLoS ONE 7:e30043

Hensen I, Kilian C, Wagner V, Durka W, Pusch J, Wesche K (2010) Low genetic variability and strong differentiation among isolated populations of the rare steppe grass Stipa capillata L. in central Europe. Plant Biol 12:526-536

Hewitt GM (1999) Post-glacial re-colonization of European biota. Biol J Linn Soc 68:87-112

Hewitt G (2000) The genetic legacy of the Quaternary ice ages. Nature 405:907-913

Hewitt GM (2004) Genetic consequences of climatic oscillation in the Quaternary. Phil Trans R Soc London B 359:183-195

Hirsch H, Wagner V, Danihelka J, Ruprecht E, Sánchez-Gómez P, Seifert M, Hensen I (2015) High genetic diversity declines towards the geographic range periphery of Adonis vernalis, a Eurasian dry grassland plant. Plant Biol 17:1233-1241

Holderegger R, Thiel-Egenter C (2008) A discussion of different types of glacial refugia used in mountain biogeography and phylogeography. J Biogeogr 36:476-480

Hulová S, Sedláček F (2008) Population genetic structure of the European ground squirrel in the Czech Republic. Conserv Gen 9:615-625

Janišová M, Bartha S, Kiehl K, Dengler J (2011) Advances in the conservation of dry grasslands-Introduction to contributions from the 7th European Dry Grassland Meeting. Plant Biosyst 145:507-513

Jankovská V, Pokorný P (2008) Forest vegetation of the last full-glacial period in the Western Carpathians (Slovakia and Czech Republic). Preslia 80:307-324

Joger U, Fritz U, Guicking D, Kalyabina-Hauf S, Nagy ZT, Wink M (2007) Phylogeography of western Palaearctic reptiles-spatial and temporal speciation patterns. Zool Anz 246:293-313

Kajtoch $€$ (2011) Conservation genetics of xerothermic beetles in Europe: the case of Centricnemus leucogrammus. J Insect Conserv 15:787-797

Kajtoch Ł, Lachowska-Cierlik D, Mazur M (2009) Genetic diversity of xerothermic weevils Polydrusus inustus and Centricnemus leucogrammus (Coleoptera: Curculionidae) in central Europe. Eur J Ent 106:325-334

Kajtoch Ł, Korotyaev B, Lachowska-Cierlik D (2012) Genetic distinctness of parthenogenetic forms of European Polydrusus weevils of the subgenus Scythodrusus. Insect Sci 19:183-194

Kajtoch Ł, Kubisz D, Lachowska-Cierlik D, Mazur MA (2013) Conservation genetics of endangered leafbeetle Cheilotoma musciformis populations in Poland. J Insect Conserv 17:67-77

Kajtoch Ł, Kubisz D, Gutowski JM, Babik W (2014a) Evolutionary units of Coraebus elatus (Coleoptera: Buprestidae) in central and eastern Europe-implications for origin and conservation. Insect Conserv Divers 7:41-54

Kajtoch Ł, Mazur M, Kubisz D, Mazur MA, Babik W (2014b) Low effective population sizes and limited connectivity in xerothermic beetles: implications for the conservation of an endangered habitat. Anim Conserv 5:454-466

Kryštufek B, Bryja J, Buzan EV (2009) Mitochondrial phylogeography of the European ground squirrel Spermophilus citellus, yields evidence on refugia for steppic taxa in the southern Balkans. Heredity 103:129-135

Kryštufek B, Ivanitskaya E, Arslan A, Arslan E, Varljen Bužan E (2012) Evolutionary history of mole rats (genus Nannospalax) inferred from mitochondrial cytochrome b sequence. Biol J Linn Soc 105:446-455

Krzakowa M, Michalak M (2007) Genetic variability of selected marginal populations of Stipa capillata L. Biol Lett 44:127-135

Kubisz D, Kajtoch Ł, Mazur MA, Lis A, Holecová M (2012) Conservation genetics of highly isolated populations of xerothermic Crioceris quatuordecimpunctata (Coleoptera: Chrysomelidae). Invertebr Biol 131:333-344

Lewandowski J (2011) „Glacial oasis” in the Cracow-Częstochowa Upland-results of studies during the last fifty years. Przegl Geol 59:732-738

Lindner L, Bogutsky A, Gozhik P, Marks L, Lanczont M, Wojnatowicz J (2006) Correlation of Pleistocene deposits in the area between the Baltic and Black Sea, Central Europe. Geol Q 50:195-210

Magyari EK, Chapman JC, Passmore DG, Allen JRM, Huntley JP, Huntley B (2010) Holocene persistence of wooded steppe in the Great Hungarian Plain. J Biogeogr 37:915-935

Magyari EK, Kuneš P, Jakab G, Sümegi P, Pelánková B, Schäbitz F, Braun M, Chytrý M (2014) Late Pleniglacial vegetation in eastern-central Europe: are there modern analogues in Siberia? Quat Sci Rev 95:60-79

Markova AK, Simakova AN, Puzachenko AY (2009) Ecosystems of Eastern Europe at the time of maximum cooling of the Valdai glaciation (24-18 kyr BP) inferred from data on plant communities and mammal assemblages. Quat Int 201:53-59 
Matrosova VA, Savinetskaya LE, Shekarova ON, Pivanova SV, Rusin MYu, Volodin IA, Volodina EV, Tchabovsky AV (2014) Within and between population polymorphism of the mtDNA control region of the speckled Ground Squirrel (Spermophilus suslicus). Biol Sci 455:143-148

Mazur M, Kubisz D (2013) Distribution and migration of the xerothermic beetles (Coleoptera) in the Vistula River valley. Monografie Faunistyczne 26. ISEZ PAN, Kraków

Mazur MA, Kubisz D, Kajtoch $Ł$ (2014) Restricted geographic distribution and low genetic distinctiveness of steppic Crioceris quinquepunctata (Coleoptera: Chrysomelidae) populations in central-east Europe. Entom Fenn 25:103-111

Meindl C (2011) New aspects in plant conservation-phylogeography, population dynamics, genetics and management of steppe plants in Bavaria. PhD thesis, Fakultät für Biologie und vorklinische Medizin, University of Regensburg, Regensburg

Moritz C (1994) Defining "Evolutionarily significant units"' for conservation. Trends Ecol Evol 9:373-375

Nagy ZT, Bellaagh M, Wink M, Paunovic A, Korsós Z (2010) Phylogeography of the Caspian whipsnake in Europe with emphasis on the westernmost populations. Amphibia-Reptilia 31:455-461

Németh A, Homonnay ZG, Krizsik V, Csorba G (2013) Old views and new insigths - taxonomic revision of the Bukovina Blind Mole Rat, Spalax graecus (Rodentia: Spalacidae). Zool J Linn Soc 169:903-914

Neumann K, Jansman H, Kayser A, Maak S, Gattermann R (2004) Multiple bottlenecks in threatened western European populations of the common hamster Cricetus cricetus (L.). Conserv Genet 5:181-193

Neumann K, Michaux JR, Maak S, Jansman HAH, Kayser A, Mundt G, Gattermann R (2005) Genetic spatial structure of European common hamsters (Cricetus cricetus) - a result of repeated range expansion and demographic bottlenecks. Mol Ecol 14:1473-1483

Nève G, Barascud B, Descimon H, Baguette M (2000) Genetic structure of Proclossiana eunomia populations at the regional scale (Lepidoptera, Nymphalidae). Heredity 84:657-666

Pärtel M, Bruun HH, Sammul M (2005) Biodiversity in temperate European grasslands: origin and conservation. In: Lillak R, Viiralt R, Linke A, Geherman V (eds) Integrating efficient grassland farming and biodiversity. Estonian Grassland Society, Tartu, pp 1-14

Pawłowska S (1966) Floristic statistics and the elements of the Polish flora. In: Szafer W (ed) The vegetation of Poland. Pergamon Press, Oxford, pp 138-240

Pecsenye K, Bereczki J, Tóth A, Meglécz E, Peregovits L, Juhász E, Varga Z (2007) A populációstruktúra és a genetikai variabilitás kapcsolata védett nappalilepke-fajainknál [Connection between population structure and genetic variability in some protected butterfly species]. In: Forró L (ed) A Kárpátmedence állatvilágának kialakulása [The formation of the fauna of the Carpathian Basin]. Magyar Természettudományi Múzeum, Budapest, pp 241-260

Petit RJ, Aguinagalde I, de Beaulieu J-L, Bittkau C, Brewer S, Cheddadi R, Ennos R, Fineschi S, Grivet D, Lascoux M, Mohnty A, Müller-Starck G, Demesure-Musch B, Palmé A, Pedro Martin J, Rendell S, Vendramin GG (2003) Glacial refugia: hotspots but not melting pots of genetic diversity. Science 300:1563-1565

Pettersson B (1965) Gotland and Öland-two limestone islands compared. Acta Phytogeogr Suec 50:131-160

Pokorný P, Chytrý M, Juřičková L, Sádlo J, Novák J, Ložek V (2015) Mid-Holocene bottleneck for central European dry grasslands: did steppe survive the forest optimum in northern Bohemia, Czech Republic? The Holocene 25:716-726

Przybyłowicz Ł, Lukhtanov V, Lachowska-Cierlik D (2014) Towards the understanding of the origin of the Polish remote population of Polyommatus (Agrodiaetus) ripartii (Lepidoptera: Lycaenidae) based on karyology and molecular phylogeny. J Zool Syst Evol Res 52:44-51

Ribera I, Blasco-Zumeta J (1998) Biogeographical links between steppe insects in the Monegros region (Aragon, NE Spain), the eastern Mediterranean, and central Asia. J Biogeogr 25:969-986

Říčanová Ś, Koshev Y, Ríčan O, Ćosić N, Ćirović D, Sedláček F, Bryja J (2013) Multilocus phylogeography of the European ground squirrel: cryptic interglacial refugia of continental climate in Europe. Mol Ecol 22:4256-4269

Rutkowski R, Sielezniew M, Szostak A (2009) Contrasting levels of polymorphism in cross-amplified microsatellites in two endangered xerothermophilous, obligatorily myrmecophilous, butterflies of the genus Phengaris (Maculinea) (Lepidoptera: Lycaenidae). Eur J Ent 106:457-469

Schmitt T (2007) Molecular biogeography of Europe: Pleistocene cycles and postglacial trends. Front Zool $4: 1-13$

Schmitt T (2009) Biogeographical and evolutionary importance of the European high mountain systems. Front Zool 6:9

Schmitt T, Haubrich K (2008) The genetic structure of the mountain forest butterfly Erebia euryale unravels the late Pleistocene and Postglacial history of the mountain forest biome in Europe. Mol Ecol $17: 2194-2207$ 
Schmitt T, Varga Z (2012) Extra-Mediterranean refugia: the rule and not the exception? Front Zool 9:1-12

Schönswetter P, Stehlik I, Holderegger R, Tribsch A (2005) Molecular evidence for glacial refugia of mountain plants in the European Alps. Mol Ecol 14:3547-3555

Schroeder O, Astrin JJ, Hutterer R (2014) White chest in the west: pelage colour and mitochondrial variation in the common hamster (Cricetus cricetus) across Europe. Acta Theriol 59:211-221

Sielezniew M, Rutkowski R (2012) Population isolation rather than ecological variation explains the genetic structure of endangered myrmecophilous butterfly Phengaris (= Maculinea) arion. J Insect Conserv $16: 39-50$

Sommer RS, Nadachowski A (2006) Glacial refugia of mammals in Europe: evidence from fossil records. Mamm Rev 36:251-265

Stewart JR, Lister AM (2001) Cryptic northern refugia and the origins of the modern biota. Trends Ecol Evol 16:608-613

Stewart JR, Lister AM, Barnes I, Dalén L (2010) Refugia revisited: individualistic responses of species in space and time. Proc R Soc B Biol Sci 277:661-671

Sutcliffe L, Germany M, Becker U, Becker T (in press) How does size and isolation affect "islands" of steppe-like vegetation on the Transylvanian Plateau? Biodivers Conserv

Szczepaniak M, Cieślak E (2011) Genetic and morphological differentiation between Melica ciliata L. and M. transsilvanica Schur (Poaceae) in Europe reveals the non-presence of M. ciliata in the Polish flora. Acta Soc Bot Pol 80:301-313

Sztencel-Jabłonka A, Mazgajski TD, Bury B, Najbar B, Rybacki M, Bogdanowicz W, Mazgajska J (2015) Phylogeography and genetic structure of smooth snake (Coronella austriaca) population—evidence for the reduced genetic pool and the genetic divide in central Europe. Biol J Linn Soc 115:195-210

Taberlet P, Fumagalli L, Wust-Saucy AG, Cossons JF (1998) Comparative phylogeography and postglacial colonization routes in Europe. Mol Ecol 7:453-464

Tóth JP, Varga Z (2011) Inter- and intraspecific variation in the genitalia of the 'Melitaea phoebe group' (Lepidoptera, Nymphalidae). Zool Anz 250:258-268

Tóth JP, Varga K, Zs Végvári, Varga Z (2012) Distribution of the Eastern Knapweed Fritillary (Melitaea ornata Christoph, 1893) (Lepidoptera: Nymphalidae): past, present and future. J Insect Conserv $17: 245-255$

Tóth JP, Bereczki J, Varga Z, Sramkó G, Wahlberg N (2014) Combined DNA and morphometric based phylogeny of the Melitaea phoebe (Lepidoptera: Nymphalidae) species group. Syst Entom 39:749-757

Varga Z (2002) Zoologische Forschungen in Zentralasien-Ergebnisse und Erlebnisse. Ber Humboldt-Ver Ung Sonderausg 21:3-53

Varga Z (2010) Extra-Mediterranean refugia, post-glacial vegetation history and area dynamics in Eastern Central Europe. In: Habel JC, Assmann T (eds) Relict species: phylogeography and conservation biology. Springe, Berlin, pp 57-87

Varga ZS, Schmitt T (2008) Types of oreal and oreotundral disjunction in the western Palearctic. Biol J Linn Soc 93:415-430

Vogler A, DeSalle R (1994) Diagnosing units of conservation management. Conserv Biol 8:354-363

Wagner V, Treiber J, Danihelka J, Ruprecht E, Wesche K, Hensen I (2012) Declining genetic diversity and increasing genetic isolation towards the range periphery of Stipa pennata, a Eurasian feather grass. Int J Plant Sci 173:802-811

Wahlberg N, Saccheri I (2007) The effects of Pleistocene glaciations on the phylogeography of Melitaea cinxia (Lepidoptera: Nymphalidae). Eur J Ent 104:675-684

Willis KJ, van Andel TA (2004) Trees or no trees? The environments of central and eastern Europe during the Last Glaciation. Quat Sci Rev 23:2369-2387

Willis KJ, Rudner E, Sümegi P (2000) The Full-Glacial forests of Central and Southeastern Europe. Quat Res 53:203-213

Wróblewska A (2008) From the center to the margins of geographical range: molecular history of steppe plant Iris aphylla L. in Europe. Plant Syst Evol 272:49-65

Wróblewska A, Brzosko E, Czarnecka B, Nowosielski J (2003) High levels of genetic diversity in populations of Iris aphylla L. (Iridaceae), an endangered species in Poland. Bot J Linn Soc 142:65-72

Wróblewska A, Brzosko E, Chudzińska E, Bordács S, Prokopiv AI (2010) Cytotype distribution and colonization history of the steppe plant Iris aphylla. Ann Bot Fenn 47:23-33

Wysota W, Molewski P, Sokolowski RJ (2009) Record of the Vistula Ice Lobe advances in the Late Weichselian glacial sequence in north-central Poland. Quat Int 207:26-41

Yurtsev BA (1982) Relics of the xerophyte vegetation of Beringia in northeastern Asia. In: Hopkins DM, Matthews JV, Schweger CE (eds) Palaeoecology of Beringia. Academic Press, London, pp 157-177

Yurtsev BA (2000) The Pleistocene "Tundra-Steppe" and the productivity paradox: the landscape approach. Quat Sci Rev 20:165-174 
Zinenko O, Stümpel N, Mazanaeva L, Bakiev A, Shiryaev C, Pavlov A, Kotenko T, Kukushkin O, Chikin Y, Duisebayeva T, Nilson G, Orlov NL, Tuniyev S, Ananjeva NB, Murphy RW, Joger U (2015) Mitochondrial phylogeny shows multiple independent ecological transitions and northern dispersion despite of Pleistocene glaciations in meadow and steppe vipers (Vipera ursinii and Vipera renardi). Mol Phylogenet Evol 84:85-100 